\title{
The cultural and heritage tourist, SEM analysis: the case of The Citadel of the Catholic King
}

\author{
Ricardo David Hernández-Rojas ${ }^{1}$, Juan Antonio Jimber del Río ${ }^{1 *} \mathbb{D}$, Alberto Ibáñez Fernández ${ }^{2}$ and \\ Arnaldo Vergara-Romero ${ }^{3}$
}

\begin{abstract}
This study researches the loyalty of travelers to destinations which include material cultural heritage. It analyzes the loyalty of visitors to a destination with cultural heritage sites in order to provide results which can be used to improve the management of the destination. This research used Warp-PLS 7.0 software with a structural equations model to evaluate the 8 proposed and validated hypotheses. A questionnaire was given to a sample of 499 tourists who visited The Citadel of the Catholic King in Córdoba and the statistical study of the replies gave results about the loyalty of visitors to a destination which includes cultural heritage. This study adds an innovative component by analyzing the moderating effect of perceived heritage quality and perceived cultural quality on the relationship of perceived value and visitor satisfaction. This study shows that visitor loyalty to The Citadel of the Catholic King depends on the visitor satisfaction with the cultural heritage, it also analyses how the quality perceived by the tourist modulates to varying degrees the relationship between perceived value and tourist satisfaction. Areas which can be improved at cultural heritage sites have been identified and these include the professionalization of tour guides specialized in cultural heritage sites, improving and showing the cultural importance of the heritage, the information available about the heritage and the access to the heritage. These findings are important for city managers when preparing projects to increase the loyalty and competitiveness of the city compared to other similar destinations with cultural heritage.
\end{abstract}

Keywords: Loyalty, Heritage tourism, Cultural heritage, Structual ecuation model, Warp-PLS

\section{Introduction}

Cultural material heritage has become a factor which can make a city more attractive to visitors. Adequate management of the heritage is essential to achieve visitor satisfaction during and after the visit as well as improve the visitor expectations before and the perceived quality after the visit. Continuous improvement of these aspects can be the differentiating factor for the loyalty of the visitor to the city. The strong competition for visitors between

\footnotetext{
*Correspondence: jjimber@uco.es

${ }^{1}$ Department Agricultural Economics, Sociology, and Policy, Faculty of Economics and Business Sciences, Universidad de Córdoba, Plaza de Puerta Nueva S/N, 14002 Cordoba, Spain

Full list of author information is available at the end of the article
}

destinations with heritage and culture sites, especially UNESCO listed sites, means that making continual improvements to the management of these sites is essential. The current situation will only become more difficult in the future [1]. In view of this, visitor loyalty to a destination is an important factor to take into account, especially for tourist destinations in areas with cultural heritage [2]. This research makes a valuable contribution to this subject [2].

The Citadel of the Catholic King is material heritage that has a lot of historical and cultural relevance. Firstly, due to the cultures that used the site. The first record of the existence of the enclave comes from Roman culture when it was used as a way to defend the city against incursions made on the Guadalquivir River. After that it

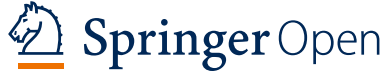

(c) The Author(s) 2021. This article is licensed under a Creative Commons Attribution 4.0 International License, which permits use, sharing adaptation, distribution and reproduction in any medium or format, as long as you give appropriate credit to the original author(s) and the source, provide a link to the Creative Commons licence, and indicate if changes were made. The images or other third party material in this article are included in the article's Creative Commons licence, unless indicated otherwise in a credit line to the material. If material is not included in the article's Creative Commons licence and your intended use is not permitted by statutory regulation or exceeds the permitted use, you will need to obtain permission directly from the copyright holder. To view a copy of this licence, visit http://creativeco mmons.org/licenses/by/4.0/. The Creative Commons Public Domain Dedication waiver (http://creativecommons.org/publicdomain/ zero/1.0/) applies to the data made available in this article, unless otherwise stated in a credit line to the data. 
became the center of Arabic culture in Spain, being used as the residence of the city rulers. After the reconquest of Cordoba by the Catholic kings, it was transformed into a building where the monarchs could rest and relax. The Citadel of the Catholic King is also a place where important historical changes for Spain and the world happened. It was the place where Cristopher Columbus met the Catholic Kings, who were the Monarchs that unified Spain into a Kingdom [3]. The building that can be visited today was built by Alfonso XI in 1328 on the site of the Omeya Citadel (Arabic origin) [4]. From 1492 to 1811, it was owned by the holy Catholic inquisition. From 1822 to 1931 it was a prison and later used as a military installation until its transfer in 1955 to the Córdoba City Council, which now owns it and manages it as a tourist site [5]. The Alcázar was classified as a Historical Monument in 1931 and is in the area in Córdoba that was declared a World Heritage Site by UNESCO in 1994. Currently, The Citadel of the Catholic King is the third most visited material heritage in Cordoba, the second being the synagogue of Cordoba and the first is the Mosque-Cathedral. In 2019 it had 615,737 tourist visits, and an average growth in visits of $10.69 \%$ in the last 10 years (Observatorio de turismo de Córdoba, 2019).

This study is based in the American Customer Satisfaction Index (ACSI) [6], which is a model that has been fully tested for use in research on tourism [7], tourist satisfaction [8], heritage [9] and culture [10].

"The ACSI model has been used in multiple studies of satisfaction and loyalty in tourism in general and in heritage tourism [11-19].

The model is based on the expectations that are created before visiting a heritage tourism destination (expected quality). Tourists once they arrive at their destination, live the experience at destination, perceive the quality of different factors that build the perceived quality. Both constructs, (expected quality and perceived quality) relate to the perceived value, which compares the balance or imbalance between perceived cost at its destination and the value received at it. Once the tourist has internalized the perceived value, he is able to assess the level of satisfaction at the destination. The satisfaction level allows you to decide to recommend and repeat the destination (Loyalty)."

This study expands the existing literature about the satisfaction and loyalty of heritage and cultural tourists, since the expected quality of the heritage and cultural aspects are separated, as are the perceived cultural quality and the perceived heritage quality. The concept of moderating constructs is also added to the classic theory of the Structural Equation Model. Two hypotheses specifically analyze the modulating effect of the constructs perceived cultural quality and perceived heritage quality of the visiting tourist. This study is configured as follows: first the introduction, secondly there is the theoretical framework that explains the constructs of the theoretical model and structural equations, below explains the methodology used and the fourth section summarizes the results of the research. To finish the article we find the discussion and conclusions of the study, followed by a list of the references used in the article.

In recent decades Cultural tourism occupies a niche market with exponential growth in international tourism [20]. Visiting tourists have motivations perceptions and build their idea of satisfactory destination based on various factors. Cultural and heritage, as an important part of the demand for knowledge of the place visited, create the experience of the tourist's visit that allows to have the ability to make the decision to return, recommend and promote the destination as a prominent part of his historical heritage experience [21]. World heritage cities compete to offer recreational and cultural experiences that attract the greatest number of tourists with the desire to learn more about the history of the destination, enriching their knowledge and their life experience [22]. Ramires, Brandao, and Sousa describes cultural historical tourism as a social phenomenon [23]. Cultural heritage cities have to differentiate the difference from the competition, either including in their cultural offer local customs, centuries of history, art and traditions transmitted from generation to generation. Consequently, heritage tourism is important for the cities that have heritage sites [24].

In this context, the components that are related to satisfaction in the visit to the material heritage can cite how visitors seek new experiences, authentic contexts and unique or exceptional activities. Actions such as participation, hedonism, knowledge, nostalgia, history, novelty and local culture are the basic ingredients of a memorable and satisfying tourist experience [25], in the same line the authors [26] highlight how the experiences provided in the heritage present the same degree of satisfaction for visitors that aims to visit the material heritage itself as those who visit the heritage for the tourist experiences around it (theatrical visits, historical explanations). This, coupled with the fact that these activities are usually carried out on holidays and that holiday contribute to the satisfaction of life and its quality of life [27-29] in addition to adding congratulations and pleasurable effects to the activities carried out in the holiday period [30].

Studies have shown that loyalty to a visited place is directly related to the satisfaction and opinion of the visitor [31, 32]. Studies which analyze loyalty in tourism have mainly looked into the attitude and intention of the visitor [32]. Academic studies can be grouped into two categories due to how loyalty is examined. The first 
group investigates repeat purchases, that is to say, tourists returning to a destination. The second, and far more interesting, group takes loyalty to mean recommending the tourist destination to other future tourists [3335]. This means that the tourist feels a connection with a destination and intends to visit it again in the future, while also recommending it to third parties [36-39]. It should be pointed out that there are authors who warn that a tourist's desire for new experiences may counteract the loyalty shown to the destination [40]. Studies which investigate loyalty to cultural heritage are mainly cognitive and use structural equations to predict intentions to return to or recommend a destination [41, 42].

How comfortable the tourist felt at the destination and the monument visited is one of the most important factors when deciding to return to a destination, and therefore for visitor loyalty [35, 38, 43]. The perceived quality is usually considered one of the most important factors in research on tourist behavior [44]. Researchers define perceived quality as the overall accumulation of the tourist's feelings about the experience at a destination $[45,46]$. Tourists value their experience as positive or negative for different attributes of the monument or destination [80]. Following on from this idea, the perceived value of a destination by a visitor is considered to be the most important indicator of their intentions to return to the chosen destination. It is possible that a customer does not buy a product or service because it is not considered value for money as the perceived value is not adequate for the price asked [47]. Studies by different authors explain that perceived value measures a tourist's general assessment of their experience at a destination from the feelings they had there $[48,49]$. Cossío-Silva et al. obtain a realistic idea of tourist behavior by means of this variable and the results obtained can be useful for public institutions and organizations that offer tourism [50]. Customers who are aware of the value of a service or product sometimes expect particular benefits from it [51]. For this reason, perceived value is related to the usefulness of a purchase because the purchase has intrinsic benefits that satisfy the buyer's needs [52]. A tourist who is interested in value will look for information and contemplate the idea fully before making a decision [53]. This means that perceived value affects the decisions of customers [54]. Perceived value can positively affect the loyalty of a customer [47] because customers who are aware of the value of a service make positive judgements about it, relating value to price and critically assessing all options.

This study analyses the relationship between the following variables, perceived heritage quality (PPQ) and the expected heritage quality (EPQ), perceived cultural heritage quality (PCHQ) and the expected cultural heritage quality (ECHQ), the perceived value of the visit as a whole (PV), satisfaction (SATISFAC) and loyalty (LOYALTY). In literature there are several studies including these variables, however few studies include modulating variables in the relationships between constructs $[55,56]$. The different authors who have used this type of theoretical model are shown in Table 1.

The questionnaire with which the data was obtained was designed following various authors who have used constructs similar to those used in the theoretical model. The ACSI model has been used in multiple studies of satisfaction and loyalty in tourism in general and in heritage tourism [11-19].

The model is based on the expectations that are created before visiting a heritage tourism destination (expected quality). Tourists once they arrive at their destination, live the experience at destination, perceive the quality of different factors that build the perceived quality. Both constructs, (expected quality and perceived quality) relate to the perceived value, which compares the balance or imbalance between perceived cost at its destination and the value received at it. Once the tourist has internalized the perceived value, he is able to assess the level of satisfaction at the destination. The satisfaction level allows you to decide to recommend and repeat the destination (loyalty).

The variables which were investigated in this study are satisfaction and loyalty. These have been studied on several occasions in different areas by several authors [57, 58]. Both variables are positively related showing that the probability of a visitor at a heritage site revisiting or recommending the destination is high $[59,60]$ if they are satisfied with the visit. These are judgments made by tourists because of their experience at the destination, and these affect the likelihood of the tourist revisiting the site or city and their willingness to recommend it to friends and family $[2,61]$.

Managers of cultural material heritage should have previous information about the visitors who visit the site in order to plan actions which will improve the visitor expectations about the heritage and cultural experiences. These modify the behavior of the tourist because of the relationship between the perceived value and satisfaction. This study uses structural equations with all the above variables and, as it also includes a new approach using moderating relationships at heritage sites, it is of academic interest. This research increases the contribution to academic literature around heritage, loyalty and satisfaction by adding culture on the visit.

There are not many Royal and historical Citadels (with a past dated at least from the Muslim era) in Spain which are put in tourist value and are visitable. The uniqueness that were the quarters of the Catholic kings, with a historical character and that are touristic. In particular, 
Table 1 Scales used

\begin{tabular}{|c|c|c|}
\hline References & Dimension & Indicators \\
\hline$[44,67-71]$ & $(E P Q)$ & $\begin{array}{l}\text { (EPQ1) Expected Quality of the Arabic heritage at the Citadel, (EPQ2) Heritage Conservation, (EPQ3) } \\
\text { Expected Quality of the Heritage, (EPQ4) Quality of the Heritage of the Christian heritage at the Citadel, } \\
\text { (EPQ5) The mosaic hall, (EPQ6) The tower, (EPQ7) The gardens as heritage }\end{array}$ \\
\hline$[44,67-69,72-75]$ & $(\mathrm{ECHQ})$ & $\begin{array}{l}\text { (ECHQ8) Normal visit entrance price, (ECHQ9) Expected quality of the Arabic heritage at the Citadel, } \\
\text { (ECHQ10) Expected Quality of the Christian heritage at the Citadel, (ECHQ11) Information about the his- } \\
\text { tory of the monument, (ECHQ12) Parks and gardens, (ECHQ13) Existing public lighting. Historical lighting, } \\
\text { (ECHQ14) Historical conservation of the Citadel before entering, (ECHQ15) Cultural activities, (ECHQ16) } \\
\text { Social and cultural facilities, (ECHQ17) I knew the Citadel was a UNESCO-listed city before arriving in } \\
\text { Córdoba, (ECHQ18) Social activities, (ECHQ19) The guides know sufficient language to explain the visit, } \\
\text { (ECHQ20) The website and internet information about the Citadel is interesting, (ECHQ21) Recordings } \\
\text { explain the history of the heritage, (ECHQ22) COVID measures are complied with, and (ECHQ23) the qual- } \\
\text { ity of this type of heritage }\end{array}$ \\
\hline$[1,44,76-78]$ & $(\mathrm{PPQ})$ & $\begin{array}{l}\text { (PPQ1) Heritage Quality of the historical Arabic heritage at the Citadel, (PPQ2) Heritage Conservation, (PPQ3) } \\
\text { Quality of the cutltural visit, (PPQ4) Quality of the historial Christian heritage of the Citadel, (PPQ5) The } \\
\text { mosaic hall, (PPQ6) The tower, (PPQ7) The gardens as heritage }\end{array}$ \\
\hline$[77,79-82]$ & $(\mathrm{PCHQ})$ & $\begin{array}{l}\text { (PCHQ8) Normal visit entrance price (PCHQ9) Quality of the historical Arabic heritage at the Citadel, } \\
\text { (PCHQ10) Quality of the historical Christian heritage at the Citadel, (PCHQ11) Information available about } \\
\text { the history of the monument, (PCHQ12) Parks and gardens, (PCHQ13) Existing public lighting. Historical } \\
\text { lighting, (PCHQ14) Historical conservation of the Citadel before entering, (PCHQ15) Cultural activities, } \\
\text { (PCHQ16) Social and cultural facilities, (PCHQ17) I knew the Citadel was a UNESCO-listed city before arriv- } \\
\text { ing in Córdoba, (PCHQ18) Social activities, (PCHQ19) The guides know sufficient language and to explain } \\
\text { the visit, (PCHQ20) The website and internet information about the Citadel is interesting, (PCHQ21) Record- } \\
\text { ings explain the history of the heritage, (PCHQ22) Complies with COVID measures and the quality of this } \\
\text { type of heritage, (PCHQ23), reflects the citadel's culture of the past (PCHQ24), the cultural itinerary is well } \\
\text { designed }\end{array}$ \\
\hline$[76,83-87]$ & Perceived value (PV) & $\begin{array}{l}\text { (PV5) Normal visit entrance price (PV7) Parks and gardens, (PV8) Existing public lighting. Historical lighting, } \\
\text { (PV9) The mosaic hall, (PV10) The tower, (PV11) The gardens as heritage (PV12) Historical conservation of } \\
\text { the Citadel before entering, (PV13) The guides know sufficient language and to explain the visit, (PV14) } \\
\text { Social activities, (PV15) Social and cultural facilities, (PV16) Existing public lighting. Historical lighting, (PV17) } \\
\text { Recordings explain the history of heritage, (PV18) Quality of the historical Arabic heritage at the Citadel, } \\
\text { (PV19) Quality of the historical Christian heritage at the Citadel, (PV20) Historical conservation of the Cita- } \\
\text { del, (PV21) Information about the history of the monument }\end{array}$ \\
\hline$[59,60,88-92]$ & Satisfaction (Satisfac) & $\begin{array}{l}\text { (Sat1) The visit to the Citadel has been satisfactory, (Sat2) The treatment received from the tourist guides of } \\
\text { the Citadel has been satisfactory, (Sat3) The opening and closing times are adequate and are appropriate }\end{array}$ \\
\hline$[32,93-98]$ & Loyalty (Loyalty) & $\begin{array}{l}\text { (Loy 1) I would recommend visiting the Citadel to my friends and family, (Loy2) If I want to people to visit Cor- } \\
\text { doba, I will recommend the Citadel, (Loy3) I am proud that I visited Cordoba, (Loy4) I would recommend } \\
\text { that acquaintances go to Cordoba and visit the Citadel, (Loy5) I am proud that I know about and visited } \\
\text { the Alcázar and recommend it }\end{array}$ \\
\hline
\end{tabular}

there are four: Royal Citadel Sevilla, Royal Citadel Madrid, the Muslim Citadel of Valencia and the Royal Citadel Almunia (Palma de Mallorca). In academic matters, different studies have been carried out from the historical or archaeological perspective [62, 63] but not from the tourist management. The Citadel of the Catholic King of Cordoba is the most culturally, and architecturally significant. It belongs to the historic center of Cordoba being an inscription by UNESCO and is dated from roman times, an optimal conservation and valued for the tourism, therefore it is the most historical and cultural.

The aim of this study is to add to the information available about cultural heritage tourism, contribute to the improvement of the management of visits to the unique heritage sites and provide useful knowledge for cultural heritage managers and tourism companies. The most concrete objective is to detect how tourist experiences in culture and heritage increase satisfaction and loyalty by increasing visits, repetition and their recommendation. This research studies the loyalty of visitors to the cultural heritage site and to the city, along with the Satisfaction and Expectations of the tourists who visit The Citadel of the Catholic King. Scientific literature which studies cultural heritage tourism by investigating heritage and culture, and the influence on Perceived Quality at different Citadel s, is scarce. While it is true that there are some studies in tourism with modeling variables, the study in particular cases of heritage tourism in Spain (as a second country in the ranking of international tourists) is novel. It contributes to academic knowledge about the cultural and heritage aspects of material heritage. This means that it makes a contribution to the current knowledge of cultural heritage and city management.

Therefore this article contributes in several ways: first it contributes to scientific literature in the analysis of the modulation of cultural and heritage quality 
perceived in the relationship between perceived value in general and satisfaction, considering ranges of low values and high values, secondly, provides the study of the characteristics of the cultural and heritage tourism through the visit to a cultural heritage and third place, provides conclusions to achieve or loyalty improve to tourists cultural and heritage.

\section{Hypotheses development}

The variables used to measure the loyalty of the visitors to the city of Cordoba were, (1) The expected cultural quality of The Citadel of the Catholic King, (2) The expected heritage quality of The Citadel of the Catholic King, (3) The perceived cultural quality of The Citadel of the Catholic King, (4) The perceived heritage quality of The Citadel of the Catholic King, (5) Comparing the expected quality and the perceived quality we can estimate the perceived value, (6) Satisfaction, as an emotional or cognitive response of the visiting tourist, and (7) The loyalty that tourists feel as a result of their attitude and contact with the experience in destiny.

The following (Fig. 1) hypotheses were formulated using the existing literature:

Hypothesis 1 (H1) The expected patrimonial quality (EPQ) positively and significantly influences the perceived patrimonial quality (PPQ). EPQ influences PPQ.

Hypothesis 2 (H2) The expected cultural heritage quality (ECHQ) positively and significantly influences the perceived cultural heritage quality (PCHQ). ECHQ influences $\mathrm{PCHQ}$.
Hypothesis 3 (H3) The perceived cultural heritage quality positively and significantly influences the perceived value as a whole. PCHQ influences PV.

Hypothesis 4 (H4) The perceived patrimonial quality (PPQ) positively and significantly influences the perceived value (PV) as a whole. PPQ influences PV.

Hypothesis 5 (H5) The perceived patrimonial quality (PPQ) positively and significantly influences the relationship between perceived value (PV) and satisfaction (SATISFAC). PPQ moderates PV which influences SATISFAC.

Hypothesis 6 (H6) The perceived cultural heritage quality (PCHQ) positively and significantly influences the relationship between perceived value (PV) and satisfaction (SATISFAC). PCHQ moderates PV which influences SATISFAC.

Hypothesis 7 (H7) The perceived value (PV) influences the satisfaction (SATISFAC) with it. PV influences SATISFAC.

Hypothesis 8 (H8) The satisfaction of the visitor to the cultural heritage positively influences their loyalty to it. SATISFAC influences LOYALTY.

\section{Methodology}

Questionnaire and data collection

This study was conducted in Córdoba, Andalusia, Spain. Córdoba, as with its four UNESCO world heritage sites, has an extraordinary cultural and heritage offer, full of history, traditions and centuries of Arab, Jewish and Christian knowledge [64]. The data was collected with

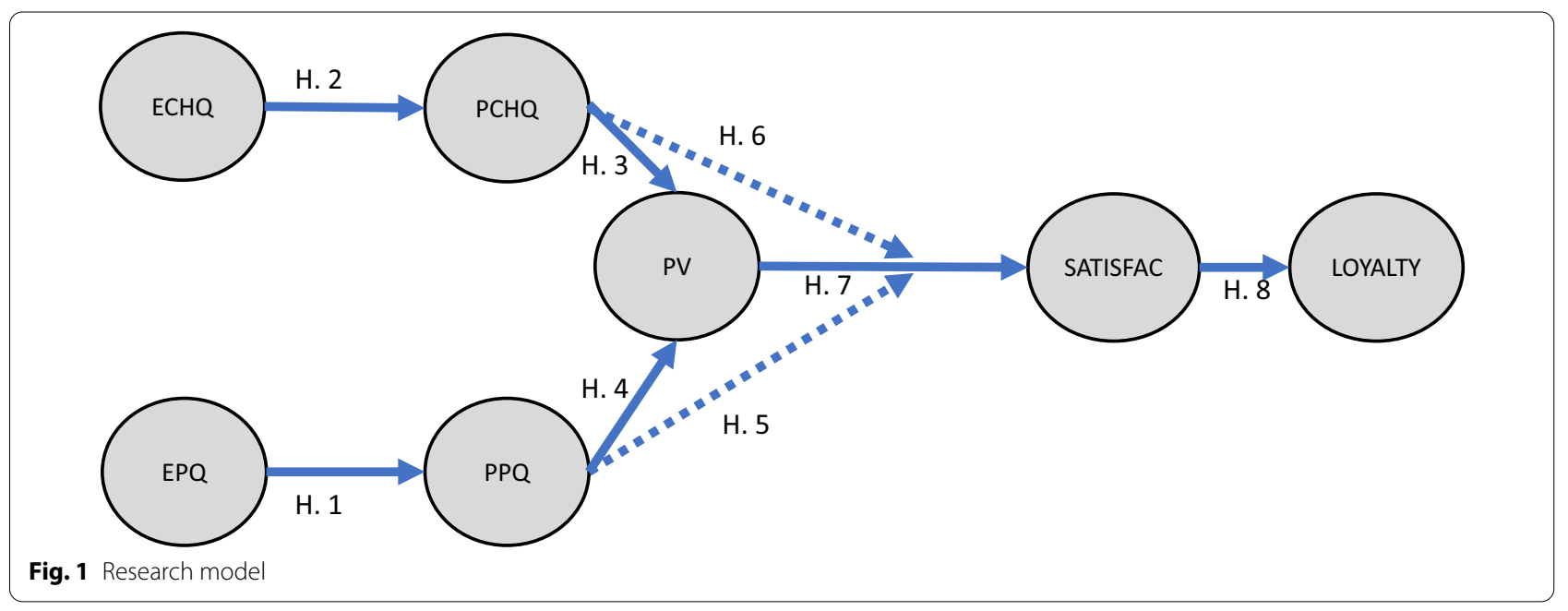


a questionnaire, which was given to tourists visiting the Citadel of the Catholic King. To ensure the validity of the questionnaire, the questions were based on previous similar studies [65]. To ensure the validity of the questionnaire, the questions were based on previous similar studies [66].

The information was collected using a questionnaire together with a personal interview with each tourist after their visit to Citadel of the Catholic King. The questionnaire was prepared in November 2019. The validation of the survey and the construction of the questions is based on consolidated indicators from previous research [114, 115]. Once the indicators had been obtained, a two-stage refining process was used. First, the indicators proposed by an investigator were analyzed, then the final survey was tested and verified by a manager at the Citadel of the Catholic King. This meant that the validity of the indicators in the constructs of the proposed research model were checked twice.

The questionnaire consisted of five sections, which were, (1) Questions about the expected heritage quality, perceived heritage quality and perceived value at The Citadel of the Catholic King, which includes the Arabic and Christian heritage of the Citadel, the conservation of the heritage site and the culture on display (2) Questions about the expected cultural quality, perceived cultural quality and perceived value at the The Citadel of the Catholic King, which includes the Arabic culture of the Citadel, the Christian culture of the Citadel and the information available about the history of the monument, etc. (3) Questions about visitor satisfaction with The Citadel of the Catholic King, (4) Questions about the loyalty of visitors to The Citadel of the Catholic King, and if they would recommend it to their family, friends, and workmates (5) Questions about the sociodemographic profile. Tourists were informed of the academic purposes and the anonymity of the study before completing the questionnaire. Verbal consent was requested before the tourist completed the questionnaire. The anonymity of the respondent was guaranteed at all times. The questions in the first four parts of the questionnaire used a sevenpoint Likert scale, where one was the answer totally disagree and seven totally agree. Participation in the study was voluntary. The questionnaire contained 68 items, the sample data was collected through a personal questionnaire at different times of the day. The questionnaire was only given to tourists who had visited the Citadel of the Catholic King and its cultural heritage. The sociodemographic profile and the details of the trip were completed with closed questions. There were 499 valid questionnaires in the sample, which had a 95\% confidence level and a sampling error of $3.25 \%$.
Research data was tabulated and analyzed using (PLSSEM), using Warp-PLS 7.0 software (ScriptWarp Systems, P.O. Box 452428, Laredo, Texas, 78045, USA).

\section{Scales}

Many authors have used in their studies the latent variables seen in Table 1.

\section{Results}

This section describes the results obtained after applying the structural equation models. First, a summary of the sociodemographic profile is shown, then the reliability and validity of the proposed model, and finally, the contrast of the eight hypotheses raised in the theoretical model.

Table 2 shows the sociodemographic profile. $45.5 \%$ of those interviewed were women, compared to 53.3 men, and $1.2 \%$ did not indicate their sex. The questionnaires were answered mainly by young people between 30 and 39 years old $(31.1 \%)$ who had studied at the university (39.7\%).

The relationship between the observed and latent variables is shown in Table 3. The structural coefficients of the normalized model have also been calculated.

\section{Analysis of the individual reliability of the items}

In order to validate the proposed model, the validity and reliability of the reflective and formative constructs were analyzed.

The formative construct (loyalty) follows the recommendations according to Sarstedt et al. Regarding the convergent validity of the constructs, all the articles proposed in the model (Table 4) had a value $>0.707$ [99].

With an analysis of the reflective constructs we can study the individual reliability of the elements with an analysis of the simple correlations of each observed variable with respect to the construct to which it belongs. Following Carmines and Zeller [100] maintaining the values of 0.707 are necessary for a variable to be accepted as part of a construct. Fifty-six of the sixty-six reflective elements have values $>0.707$, therefore we can affirm that it has good reliability for the elements that make up each first-order construct. Once individual reliability had been studied, the validity and reliability of the constructs were analyzed [101]. The analysis consisted of evaluating collinearity and verifying that the value of the inflation factor variance (VIF) is > five. The results did not show collinearity in the variables used for the loyalty construct.

Likewise, Table 5 shows the analysis of the reflective constructs (expected heritage quality, expected cultural quality, perceived heritage quality, perceived cultural quality, perceived value and satisfaction) [102]. 
Table 2 Sociodemographic profile of the visitors

\begin{tabular}{|c|c|c|c|}
\hline Variable & Category & Absolute frequency & Percentage \\
\hline \multirow[t]{4}{*}{$\operatorname{Sex}(n=499)$} & Male & 266,00 & 53,30 \\
\hline & Female & 227,00 & 45,50 \\
\hline & n.a & 6,00 & 1,20 \\
\hline & & 499,00 & 100,00 \\
\hline \multirow[t]{4}{*}{ Age $(n=499)$} & [30-39] & 155,00 & 31,06 \\
\hline & [40-49] & 164,00 & 32,87 \\
\hline & [50-59] & 138,00 & 27,66 \\
\hline & 60 or more & 42,00 & 8,42 \\
\hline \multirow[t]{6}{*}{ Studies $(n=499)$} & & 499,00 & 100,00 \\
\hline & Without studies & 2,00 & 0,20 \\
\hline & Primary school & 43,00 & 6,60 \\
\hline & Secondary school & 256,00 & 51,30 \\
\hline & University & 198,00 & 39,70 \\
\hline & & 499,00 & 97,80 \\
\hline \multirow{5}{*}{ Family income $(n=499)$} & Less than 2000 euros & 351,00 & 70,30 \\
\hline & Between 2001 and 3000 euros & 140,00 & 28,10 \\
\hline & Between 3001 and 5000 euros & 4,00 & 0,80 \\
\hline & Between 5001 and 10,000 euros & 2,00 & 0,40 \\
\hline & More than 10,001 euros & 2,00 & 0,40 \\
\hline
\end{tabular}

Italic values indicate the total sum of each section

After this analysis, we can affirm that the results indicated a quasi-optimal individual reliability, since all the load values were above the minimum required threshold of 0.505 or 0.6 according to Fornell and Larcker [103] and Barclay, Higgins and Thompson [101].

In fact, the analysis revealed that the loads were statistically significant at $99.99 \%$. Based on the results of these calculations, the measurement model was considered valid and reliable, which meant that the structural model could then be analyzed.

\section{Analysis of the reliability of the first-order constructs}

In order to confirm whether the observed variables rigorously and adequately measure the latent variable they represent, following Nunnally and Bernstein [104], the Cronbach's Alpha and composite reliability values are taken, checking if they are higher or equal to 0.7 (Table 7). As all the values exceed this lower limit, the reliability of the first order constructs and their ability to measure Loyalty are confirmed. In our analysis, all the constructs exceeded a value of 0.9 (expected heritage quality, perceived heritage quality, expected cultural quality, perceived cultural quality, perceived value and satisfaction) which means that there can be no doubt about the constructs capacity for measuring Loyalty (Table 6).

\section{Convergent validity}

To evaluate the convergent validity of a set of variables, that is, if it explains one construct and not another, the mean variance extracted (AVE) is used, it is the acceptance criterion most commonly used in research to evaluate this concept (Table 7). Fornell and Larcker [103] determined that the minimum value of the AVE must be $>0.5$, which means that the construct shares more than half of its variance with its indicators, the rest of the variance is explained by the error measurement [68]. The mean variance extracted is applicable to latent variables with reflective indicators. The nine Loyalty variables share more than $69 \%$ of their variance. Based on the results obtained, we can confirm that the measurements made are valid.

\section{Discriminatory validity}

To verify the discriminatory validity, in line with Barclay, Higgins and Thompson the cross-factor loads of indicators of a latent variable are checked against the indicator loads of the other latent variables (Table 8). Factorial loads must have greater value with their own variable than with the others evaluated in the model.

In addition, Henseler et al., in conducting simulation studies, demonstrated that the lack of validity is better detected by means of the HTMT ratio (Table 9). If the monotrait-heteromethod correlations (correlations 
Table 3 Standardized structural coefficients of the observed variables

\begin{tabular}{|c|c|c|c|c|c|c|c|}
\hline Latent variable & $\begin{array}{l}\text { Observation } \\
\text { variable }\end{array}$ & Weith & p-value & Latent variable & $\begin{array}{l}\text { Observation } \\
\text { variable }\end{array}$ & Weith & p-value \\
\hline \multirow[t]{16}{*}{ Expected cultural heritage quality } & $\mathrm{ECHQ8}$ & 0.070 & 0.057 & \multirow[t]{7}{*}{ Expected heritage quality } & EPQ1 & 0.154 & $<0.001$ \\
\hline & ECHQ9 & 0.070 & 0.057 & & EPQ2 & 0.161 & $<0.001$ \\
\hline & ECHQ11 & 0.069 & 0.060 & & EPQ3 & 0.163 & $<0.001$ \\
\hline & ECHQ12 & 0.072 & 0.052 & & EPQ4 & 0.162 & $<0.001$ \\
\hline & ECHQ13 & 0.071 & 0.056 & & EPQ5 & 0.158 & $<0.001$ \\
\hline & ECHQ14 & 0.071 & 0.055 & & EPQ6 & 0.160 & $<0.001$ \\
\hline & ECHQ15 & 0.072 & 0.052 & & EPQ7 & 0.161 & $<0.001$ \\
\hline & ECHQ16 & 0.072 & 0.053 & \multirow[t]{7}{*}{ Perceived heritage quality } & PPQ1 & 0.193 & $<0.001$ \\
\hline & ECHQ17 & 0.073 & 0.050 & & PPQ2 & 0.185 & $<0.001$ \\
\hline & ECHQ18 & 0.071 & 0.054 & & PPQ3 & 0.178 & $<0.001$ \\
\hline & ECHQ19 & 0.069 & 0.060 & & PPQ4 & 0.187 & $<0.001$ \\
\hline & ECHQ21 & 0.071 & 0.055 & & PPQ5 & 0.175 & $<0.001$ \\
\hline & ECHQ22 & 0.073 & 0.051 & & PPQ6 & 0.184 & $<0.001$ \\
\hline & ECHQ23 & 0.072 & 0.054 & & PPQ7 & 0.196 & $<0.001$ \\
\hline & $\mathrm{ECHQ24}$ & 0.072 & 0.054 & \multirow[t]{17}{*}{ Perceived value } & PV4 & 0.087 & 0.026 \\
\hline & ECHQ25 & 0.072 & 0.054 & & PV5 & 0.083 & 0.030 \\
\hline \multirow[t]{15}{*}{ Perceived cultural heritage quality } & PCHQ8 & 0.073 & 0.051 & & PV7 & 0.100 & 0.012 \\
\hline & PCHQ9 & 0.071 & 0.054 & & PV8 & 0.070 & 0.056 \\
\hline & PCHQ10 & 0.086 & 0.027 & & PV9 & 0.084 & 0.029 \\
\hline & PCHQ11 & 0.085 & 0.027 & & PV10 & 0.098 & 0.013 \\
\hline & PCHQ12 & 0.077 & 0.042 & & PV11 & 0.087 & 0.025 \\
\hline & PCHQ13 & 0.088 & 0.024 & & PV12 & 0.082 & 0.033 \\
\hline & PCHQ14 & 0.092 & 0.019 & & PV13 & 0.099 & 0.013 \\
\hline & PCHQ15 & 0.093 & 0.018 & & PV14 & 0.103 & 0.010 \\
\hline & PCHQ16 & 0.079 & 0.038 & & PV15 & 0.103 & 0.010 \\
\hline & PCHQ17 & 0.088 & 0.024 & & PV16 & 0.081 & 0.035 \\
\hline & PCHQ18 & 0.084 & 0.029 & & PV17 & 0.101 & 0.012 \\
\hline & PCHQ19 & 0.077 & 0.041 & & PV18 & 0.092 & 0.019 \\
\hline & PCHQ20 & 0.071 & 0.056 & & PV19 & 0.074 & 0.048 \\
\hline & PCHQ22 & 0.085 & 0.028 & & PV20 & 0.095 & 0.016 \\
\hline & PCHQ23 & 0.076 & 0.044 & & PV21 & 0.083 & 0.031 \\
\hline \multirow[t]{3}{*}{ Satisfaction } & Sat1 & 0.360 & $<0.001$ & \multirow[t]{5}{*}{ Loyalty } & Loy1 & 0.238 & $<0.001$ \\
\hline & Sat2 & 0.385 & $<0.001$ & & Loy2 & 0.234 & $<0.001$ \\
\hline & Sat3 & 0.381 & $<0.001$ & & Loy3 & 0.238 & $<0.001$ \\
\hline Moderated perceived cultural heritage quality & $P C H Q * P V$ & 1.000 & $<0.001$ & & Loy4 & 0.219 & $<0.001$ \\
\hline Moderated perceived heritage quality & $P P Q * P V$ & 1.000 & $<0.001$ & & Loy5 & 0.214 & $<0.001$ \\
\hline
\end{tabular}

Table 4 Reliability of individual indicators (formative)

\begin{tabular}{ll}
\hline Observed variable & Value \\
\hline Loy1 & 0.908 \\
Loy2 & 0.893 \\
Loy3 & 0.910 \\
Loy4 & 0.837 \\
Loy5 & 0.818 \\
\hline
\end{tabular}

between indicators that measure the same construct) are greater than heterotrait-heteromethod (correlations between indicators that measure different constructs) there will be discriminatory validity. Thus, the HTMT key figure must be below one (Gold et al. consider a value of 0.90 ).

In this sense, you can also use a resampling or bootstrapping to test whether the HTMT key figure is significantly different from one using the confidence interval. According to the criteria set, the confidence 
Table 5 Individual reliability of the indicators (reflective)

\begin{tabular}{|c|c|c|c|}
\hline Variable & Value & Variable & Value \\
\hline Sat1 & 0.851 & PCHQ8 & 0.627 \\
\hline Sat2 & 0.909 & PCHQ9 & 0.616 \\
\hline Sat3 & 0.900 & PCHQ10 & 0.740 \\
\hline ECHQ8 & 0.865 & PCHQ11 & 0.739 \\
\hline ECHQ9 & 0.867 & PCHQ12 & 0.664 \\
\hline ECHQ11 & 0.849 & PCHQ13 & 0.757 \\
\hline ECHQ12 & 0.892 & PCHQ14 & 0.793 \\
\hline ECHQ13 & 0.870 & PCHQ15 & 0.802 \\
\hline ECHQ14 & 0.873 & PCHQ16 & 0.680 \\
\hline ECHQ15 & 0.890 & PCHQ17 & 0.763 \\
\hline ECHQ16 & 0.884 & PCHQ18 & 0.730 \\
\hline ECHQ17 & 0.900 & PCHQ19 & 0.750 \\
\hline ECHQ18 & 0.880 & PCHQ20 & 0.668 \\
\hline ECHQ19 & 0.850 & PCHQ22 & 0.612 \\
\hline ECHQ21 & 0.881 & PCHQ23 & 0.732 \\
\hline ECHQ22 & 0.882 & PV4 & 0.647 \\
\hline ECHQ23 & 0.873 & PV5 & 0.642 \\
\hline ECHQ24 & 0.895 & PV7 & $0.76 Z$ \\
\hline ECHQ25 & 0.882 & PV8 & 0.541 \\
\hline EPQ1 & 0.862 & PV9 & 0.646 \\
\hline EPQ2 & 0.901 & PV10 & 0.757 \\
\hline EPQ3 & 0.911 & PV12 & 0.627 \\
\hline EPQ4 & 0.903 & PV13 & 0.761 \\
\hline EPQ5 & 0.881 & PV14 & 0.796 \\
\hline EPQ6 & 0.893 & PV15 & 0.792 \\
\hline EPQ7 & 0.902 & PV16 & 0.620 \\
\hline PPQ1 & 0.800 & PV17 & 0.776 \\
\hline PPQ2 & 0.767 & PV18 & 0.708 \\
\hline PPQ3 & 0.738 & PV19 & 0.569 \\
\hline PPQ4 & 0.774 & PV20 & 0.733 \\
\hline PPQ5 & 0.725 & PV21 & 0.636 \\
\hline PPQ6 & 0.762 & $P C H Q * P V$ & 1.000 \\
\hline PPQ7 & 0.812 & $P P Q^{*} P V$ & 1.000 \\
\hline
\end{tabular}

Table 6 Composite reliability and Cronbach's Alpha

\begin{tabular}{llll}
\hline Construct & & $\begin{array}{l}\text { Composite } \\
\text { reliability }\end{array}$ & $\begin{array}{l}\text { Cronbach's } \\
\text { Alpha }\end{array}$ \\
\hline Expected heritage quality & $\mathrm{EPQ}$ & 0.965 & 0.958 \\
Expected cultural quality & $\mathrm{ECHQ}$ & 0.982 & 0.980 \\
Perceived heritage quality & $\mathrm{PPQ}$ & 0.910 & 0.884 \\
Perceived cultural quality & $\mathrm{PCHQ}$ & 0.946 & 0.939 \\
Perceived value & $\mathrm{PV}$ & 0.936 & 0.926 \\
Satisfaction & SATIFAC & 0.917 & 0.864 \\
Loyalty & LOYALTY & 0.942 & 0.922 \\
Moderated perceived cultural & PCHQ*PV & 1.000 & 1.000 \\
$\quad$ quality & & & \\
Moderated perceived heritage & $\mathrm{PPQ}$ quality & 1.000 & 1.000 \\
\hline
\end{tabular}

Table 7 Average variance extracted

\begin{tabular}{lll}
\hline Construct & & $\begin{array}{l}\text { Average variance } \\
\text { extracted (AVE) }\end{array}$ \\
\hline Expected heritage quality & $\mathrm{EPQ}$ & 0.893 \\
Expected cultural quality & $\mathrm{ECHQ}$ & 0.877 \\
Perceived heritage quality & $\mathrm{PPQ}$ & 0.769 \\
Perceived cultural quality & $\mathrm{PCHQ}$ & 0.713 \\
Perceived value & $\mathrm{PV}$ & 0.693 \\
Satisfaction & SATIFAC & 0.887 \\
Moderated perceived cultural quality & $\mathrm{PCHQ}$ PV & 1.000 \\
Moderated perceived heritage quality & $\mathrm{PPQ} P \mathrm{PV}$ & 1.000 \\
\hline
\end{tabular}

intervals for the HTMT must be less than one, allowing this criterion to be validated (Table 10).

\section{Hypothesis testing}

To verify the goodness-of-fit of the proposed model, different parameters that address said goodness were calculated in Tables 11 and 12.

Once all the constructs (reflective and formative) have been verified and validated as well as the goodness of the fit of the model, we can affirm that the results obtained are adequate and justify their validity and applicability.

Then the significance of the Path Coefficient of each hypothesis was calculated (Table 13). This showed that all the hypotheses are compatible $(\mathrm{H} 1, \mathrm{H} 2, \mathrm{H} 3, \mathrm{H} 4, \mathrm{H} 5$, $\mathrm{H} 6, \mathrm{H} 7$ and $\mathrm{H} 8$ ).

Hypotheses $\mathrm{H} 1, \mathrm{H} 2, \mathrm{H} 3, \mathrm{H} 4, \mathrm{H} 5, \mathrm{H} 6, \mathrm{H} 7$ and $\mathrm{H} 8$ were all supported. This means that there is a positive and significant relationship between the expected and perceived cultural quality, and the expected and perceived heritage quality. There is also a positive and significant relationship between perceived cultural and heritage quality and the overall perceived value. The perceived cultural quality has a positive and significant moderating influence on the relationship between perceived value and satisfaction of the visiting tourist. There is a positive and significant relationship between the satisfaction and loyalty of visitors at the heritage site.

Figure 2 shows the values of the structural coefficients of the constructs. The limiting probability (p-value) of each one is used to validate the importance of the relationships between the constructs of the proposed model.

\section{Discussion and conclusion}

The satisfaction of the tourists who visit cities with cultural heritage is the determining factor for loyalty to the city. The tourists and visitors who would repeat 
Table 8 Cross-factorial loads

\begin{tabular}{|c|c|c|c|c|c|c|c|c|c|}
\hline & EPQ & ECHQ & PPQ & PCHQ & PV & SATISFAC & LOYALTY & PCHQ*PV & $P P Q * P V$ \\
\hline EPQ1 & 0.862 & 0.759 & 0.662 & 0.593 & 0.602 & 0.41 & 0.306 & 0.576 & 0.596 \\
\hline EPQ2 & 0.901 & 0.804 & 0.657 & 0.592 & 0.61 & 0.395 & 0.283 & 0.584 & 0.607 \\
\hline EPQ3 & 0.911 & 0.809 & 0.62 & 0.573 & 0.601 & 0.417 & 0.312 & 0.524 & 0.541 \\
\hline EPQ4 & 0.903 & 0.854 & 0.678 & 0.654 & 0.68 & 0.466 & 0.344 & 0.518 & 0.549 \\
\hline EPQ5 & 0.881 & 0.772 & 0.584 & 0.514 & 0.56 & 0.372 & 0.259 & 0.539 & 0.527 \\
\hline EPQ6 & 0.893 & 0.802 & 0.634 & 0.592 & 0.6 & 0.398 & 0.276 & 0.523 & 0.531 \\
\hline EPQ7 & 0.902 & 0.88 & 0.702 & 0.696 & 0.722 & 0.444 & 0.285 & 0.569 & 0.61 \\
\hline ECHQ8 & 0.838 & 0.865 & 0.656 & 0.681 & 0.688 & 0.379 & 0.27 & 0.589 & 0.609 \\
\hline ECHQ9 & 0.848 & 0.867 & 0.635 & 0.642 & 0.664 & 0.393 & 0.304 & 0.548 & 0.57 \\
\hline ECHQ11 & 0.785 & 0.849 & 0.631 & 0.698 & 0.666 & 0.413 & 0.277 & 0.559 & 0.564 \\
\hline ECHQ12 & 0.834 & 0.892 & 0.624 & 0.68 & 0.683 & 0.426 & 0.33 & 0.57 & 0.57 \\
\hline ECHQ13 & 0.768 & 0.87 & 0.625 & 0.712 & 0.709 & 0.463 & 0.335 & 0.545 & 0.581 \\
\hline ECHQ14 & 0.779 & 0.873 & 0.602 & 0.695 & 0.676 & 0.422 & 0.295 & 0.507 & 0.524 \\
\hline ECHQ15 & 0.771 & 0.89 & 0.597 & 0.692 & 0.69 & 0.424 & 0.318 & 0.501 & 0.514 \\
\hline ECHQ16 & 0.81 & 0.884 & 0.588 & 0.636 & 0.647 & 0.388 & 0.287 & 0.519 & 0.521 \\
\hline ECHQ17 & 0.787 & 0.9 & 0.601 & 0.687 & 0.695 & 0.465 & 0.298 & 0.509 & 0.528 \\
\hline ECHQ18 & 0.783 & 0.88 & 0.589 & 0.651 & 0.659 & 0.428 & 0.305 & 0.531 & 0.545 \\
\hline ECHQ19 & 0.753 & 0.85 & 0.499 & 0.571 & 0.595 & 0.381 & 0.306 & 0.444 & 0.434 \\
\hline ECHQ21 & 0.801 & 0.881 & 0.599 & 0.678 & 0.671 & 0.452 & 0.309 & 0.48 & 0.498 \\
\hline ECHQ22 & 0.791 & 0.882 & 0.573 & 0.663 & 0.648 & 0.448 & 0.321 & 0.515 & 0.521 \\
\hline ECHQ23 & 0.815 & 0.873 & 0.56 & 0.604 & 0.61 & 0.426 & 0.296 & 0.472 & 0.501 \\
\hline ECHQ24 & 0.793 & 0.895 & 0.559 & 0.654 & 0.646 & 0.475 & 0.335 & 0.476 & 0.489 \\
\hline ECHQ25 & 0.796 & 0.882 & 0.543 & 0.621 & 0.614 & 0.427 & 0.298 & 0.475 & 0.491 \\
\hline PPQ1 & 0.558 & 0.49 & 0.8 & 0.623 & 0.621 & 0.464 & 0.434 & 0.355 & 0.396 \\
\hline PPQ2 & 0.501 & 0.465 & 0.767 & 0.604 & 0.583 & 0.35 & 0.296 & 0.268 & 0.324 \\
\hline PPQ3 & 0.44 & 0.391 & 0.738 & 0.522 & 0.47 & 0.337 & 0.331 & 0.261 & 0.272 \\
\hline PPQ4 & 0.539 & 0.488 & 0.774 & 0.587 & 0.603 & 0.469 & 0.393 & 0.349 & 0.368 \\
\hline PPQ5 & 0.623 & 0.573 & 0.725 & 0.571 & 0.597 & 0.379 & 0.351 & 0.421 & 0.427 \\
\hline PPQ6 & 0.624 & 0.599 & 0.762 & 0.684 & 0.703 & 0.575 & 0.459 & 0.333 & 0.401 \\
\hline PPQ7 & 0.619 & 0.626 & 0.812 & 0.713 & 0.708 & 0.468 & 0.376 & 0.434 & 0.483 \\
\hline PCHQ8 & 0.467 & 0.498 & 0.628 & 0.627 & 0.577 & 0.287 & 0.264 & 0.319 & 0.362 \\
\hline PCHQ9 & 0.394 & 0.434 & 0.603 & 0.616 & 0.588 & 0.331 & 0.355 & 0.257 & 0.281 \\
\hline PCHQ10 & 0.604 & 0.614 & 0.664 & 0.74 & 0.71 & 0.445 & 0.409 & 0.387 & 0.424 \\
\hline PCHQ11 & 0.484 & 0.522 & 0.581 & 0.739 & 0.644 & 0.402 & 0.305 & 0.327 & 0.369 \\
\hline PCHQ12 & 0.538 & 0.583 & 0.568 & 0.753 & 0.703 & 0.451 & 0.327 & 0.385 & 0.417 \\
\hline PCHQ13 & 0.477 & 0.542 & 0.615 & 0.664 & 0.576 & 0.333 & 0.332 & 0.277 & 0.295 \\
\hline PCHQ14 & 0.498 & 0.543 & 0.593 & 0.757 & 0.717 & 0.487 & 0.442 & 0.305 & 0.348 \\
\hline PCHQ15 & 0.513 & 0.581 & 0.58 & 0.793 & 0.764 & 0.56 & 0.442 & 0.34 & 0.391 \\
\hline PCHQ16 & 0.516 & 0.605 & 0.598 & 0.802 & 0.774 & 0.552 & 0.445 & 0.342 & 0.372 \\
\hline PCHQ17 & 0.338 & 0.42 & 0.528 & 0.68 & 0.637 & 0.371 & 0.308 & 0.209 & 0.23 \\
\hline PCHQ18 & 0.466 & 0.566 & 0.547 & 0.763 & 0.738 & 0.512 & 0.344 & 0.307 & 0.325 \\
\hline PCHQ19 & 0.473 & 0.55 & 0.587 & 0.73 & 0.663 & 0.39 & 0.333 & 0.277 & 0.308 \\
\hline PCHQ20 & 0.572 & 0.63 & 0.606 & 0.75 & 0.721 & 0.495 & 0.372 & 0.336 & 0.368 \\
\hline PCHQ22 & 0.547 & 0.583 & 0.529 & 0.668 & 0.65 & 0.527 & 0.366 & 0.356 & 0.362 \\
\hline PCHQ23 & 0.489 & 0.529 & 0.521 & 0.612 & 0.57 & 0.417 & 0.39 & 0.347 & 0.348 \\
\hline PCHQ24 & 0.442 & 0.518 & 0.5 & 0.732 & 0.678 & 0.545 & 0.452 & 0.244 & 0.253 \\
\hline PV5 & 0.638 & 0.594 & 0.647 & 0.558 & 0.647 & 0.436 & 0.281 & 0.448 & 0.464 \\
\hline PV7 & 0.616 & 0.568 & 0.62 & 0.54 & 0.642 & 0.388 & 0.326 & 0.414 & 0.429 \\
\hline PV8 & 0.639 & 0.643 & 0.741 & 0.703 & 0.768 & 0.547 & 0.403 & 0.418 & 0.482 \\
\hline
\end{tabular}


Table 8 (continued)

\begin{tabular}{|c|c|c|c|c|c|c|c|c|c|}
\hline & EPQ & $\mathrm{ECHQ}$ & PPQ & PCHQ & PV & SATISFAC & LOYALTY & $\mathrm{PCHQ}^{*} \mathrm{PV}$ & $P P Q * P V$ \\
\hline PV9 & 0.309 & 0.327 & 0.501 & 0.509 & 0.541 & 0.276 & 0.263 & 0.175 & 0.236 \\
\hline PV10 & 0.399 & 0.434 & 0.549 & 0.582 & 0.646 & 0.317 & 0.326 & 0.243 & 0.279 \\
\hline PV11 & 0.632 & 0.641 & 0.645 & 0.706 & 0.757 & 0.453 & 0.392 & 0.398 & 0.44 \\
\hline PV12 & 0.479 & 0.55 & 0.568 & 0.643 & 0.627 & 0.334 & 0.303 & 0.283 & 0.31 \\
\hline PV13 & 0.506 & 0.55 & 0.545 & 0.735 & 0.761 & 0.524 & 0.453 & 0.31 & 0.358 \\
\hline PV14 & 0.507 & 0.561 & 0.548 & 0.761 & 0.796 & 0.565 & 0.45 & 0.324 & 0.365 \\
\hline PV15 & 0.48 & 0.559 & 0.543 & 0.742 & 0.792 & 0.564 & 0.457 & 0.314 & 0.35 \\
\hline PV16 & 0.22 & 0.276 & 0.411 & 0.57 & 0.62 & 0.394 & 0.309 & 0.102 & 0.15 \\
\hline PV17 & 0.488 & 0.563 & 0.526 & 0.732 & 0.776 & 0.538 & 0.355 & 0.29 & 0.321 \\
\hline PV18 & 0.486 & 0.547 & 0.55 & 0.689 & 0.708 & 0.415 & 0.311 & 0.294 & 0.319 \\
\hline PV19 & 0.283 & 0.352 & 0.451 & 0.534 & 0.569 & 0.326 & 0.335 & 0.135 & 0.157 \\
\hline PV18_2 & 0.538 & 0.59 & 0.543 & 0.69 & 0.733 & 0.508 & 0.357 & 0.306 & 0.346 \\
\hline PV19_2 & 0.467 & 0.504 & 0.457 & 0.605 & 0.636 & 0.519 & 0.341 & 0.294 & 0.313 \\
\hline S1 & 0.452 & 0.459 & 0.546 & 0.567 & 0.593 & 0.851 & 0.561 & 0.205 & 0.248 \\
\hline S2 & 0.409 & 0.435 & 0.48 & 0.588 & 0.601 & 0.909 & 0.66 & 0.153 & 0.179 \\
\hline S3 & 0.378 & 0.401 & 0.485 & 0.532 & 0.537 & 0.9 & 0.693 & 0.14 & 0.166 \\
\hline L1 & 0.279 & 0.293 & 0.429 & 0.451 & 0.447 & 0.626 & 0.908 & 0.051 & 0.061 \\
\hline L2 & 0.255 & 0.258 & 0.398 & 0.411 & 0.41 & 0.583 & 0.893 & 0.019 & 0.03 \\
\hline L3 & 0.251 & 0.267 & 0.424 & 0.461 & 0.452 & 0.664 & 0.91 & 0.018 & 0.043 \\
\hline$\llcorner 4$ & 0.276 & 0.315 & 0.423 & 0.474 & 0.465 & 0.631 & 0.837 & 0.02 & 0.056 \\
\hline L5 & 0.393 & 0.4 & 0.48 & 0.494 & 0.482 & 0.65 & 0.818 & 0.11 & 0.158 \\
\hline $\mathrm{PCHQ}^{*} \mathrm{PV}$ & 0.613 & 0.587 & 0.45 & 0.431 & 0.434 & 0.186 & 0.049 & 1.000 & 0.911 \\
\hline$P P Q * P V$ & 0.633 & 0.603 & 0.498 & 0.469 & 0.485 & 0.221 & 0.078 & 0.911 & 1.000 \\
\hline
\end{tabular}

Table 9 Ratio HTMT

\begin{tabular}{|c|c|c|c|c|c|c|}
\hline & EPQ & $\mathrm{ECHQ}$ & PPQ & PCHQ & PV & SATISFAC \\
\hline \multicolumn{7}{|l|}{$E P Q$} \\
\hline $\mathrm{ECHQ}$ & 0.938 & & & & & \\
\hline PPQ & 0.789 & 0.726 & & & & \\
\hline $\mathrm{PCHQ}$ & 0.711 & 0.785 & 0.883 & & & \\
\hline PV & 0.740 & 0.786 & 0.885 & 0.999 & & \\
\hline SATISFAC & 0.511 & 0.528 & 0.649 & 0.702 & 0.721 & \\
\hline LOYALTY & 0.354 & 0.369 & 0.546 & 0.565 & 0.557 & 0.808 \\
\hline
\end{tabular}

Table 1090 pct. conf. intervals for HTMT ratios

\begin{tabular}{|c|c|c|c|c|c|c|c|c|c|c|c|c|}
\hline EPQ & \multicolumn{2}{|l|}{ EPQ } & \multicolumn{2}{|l|}{$\mathrm{ECHQ}$} & \multicolumn{2}{|l|}{ PPQ } & \multicolumn{2}{|l|}{ PCHQ } & \multicolumn{2}{|l|}{$\mathrm{PV}$} & \multicolumn{2}{|c|}{ SATISFAC } \\
\hline $\mathrm{ECHQ}$ & 0.865 & 0.999 & & & & & & & & & & \\
\hline PPQ & 0.717 & 0.861 & 0.654 & 0.797 & & & & & & & & \\
\hline $\mathrm{PCHQ}$ & 0.640 & 0.782 & 0.713 & 0.856 & 0.811 & 0.956 & & & & & & \\
\hline PV & 0.669 & 0.811 & 0.714 & 0.858 & 0.813 & 0.958 & 0.927 & 1.074 & & & & \\
\hline SATISFAC & 0.442 & 0.581 & 0.459 & 0.598 & 0.578 & 0.719 & 0.631 & 0.773 & 0.650 & 0.792 & & \\
\hline LOYALTY & 0.286 & 0.422 & 0.301 & 0.437 & 0.476 & 0.615 & 0.495 & 0.635 & 0.488 & 0.627 & 0.736 & 0.880 \\
\hline
\end{tabular}


Table 11 Goodness-of-fit

\begin{tabular}{|c|c|c|}
\hline Goodness-of-fit & & \\
\hline Average path coefficient (APC) & 0.504 & $P<0.001$ \\
\hline Standardized Chi-squared with 2484 degrees of freedom (SChS) & 37.522 & \\
\hline$x^{2} / d f$ & 0.015 & \\
\hline Average R-squared (ARS) & 0.599 & \\
\hline Average adjusted R-squared (AARS) & 0.597 & \\
\hline Average VIF (AVIF) & 2.796 & Acceptable if $\leq 5$, ideally $\leq 3.3$ \\
\hline Sympson's paradox ratio (SPR) & 0.875 & Acceptable if $\geq 0.7$, ideally $=1$ \\
\hline Tenenhaus GoF (GoF) & 0.668 & Small $\geq 0.1$, medium $\geq 0.25$, large $\geq 0.36$ \\
\hline R-squared contribution ratio (RSCR) & 0.989 & Acceptable if $\geq 0.9$, ideally $=1$ \\
\hline Sympson's paradox ratio (SPR) & 0.875 & Acceptable if $\geq 0.7$, ideally $=1$ \\
\hline Statistical suppression ratio (SSR) & 1.000 & Acceptable if $\geq 0.7$ \\
\hline Nonlinear bivariate causality direction ratio (NLBCDR) & 1.000 & \\
\hline Standardized root mean squared residual (SRMR) & 0.079 & Acceptable if $\leq 0.1$ \\
\hline Standardized mean absolute residual (SMAR) & 0.059 & \\
\hline Standardized threshold difference count ratio (STDCR) & 0.985 & Acceptable if $\geq 0.7$, ideally $=1$ \\
\hline Standardized threshold difference sum ratio (STDSR) & 0.927 & \\
\hline
\end{tabular}

Table 12 R squared and $Q$ squared

\begin{tabular}{|c|c|c|c|c|c|c|c|}
\hline & EPQ & ECHQ & PPQ & PCHQ & PV & SATISFAC & LOYALTY \\
\hline R squared & & & 0.564 & 0.603 & 0.882 & 0.415 & 0.529 \\
\hline Adj. R squared & & & 0.564 & 0.602 & 0.882 & 0.411 & 0.528 \\
\hline Q square & & & 0.559 & 0.597 & 0.881 & 0.446 & 0.529 \\
\hline
\end{tabular}

Table 13 Hypothesis testing

\begin{tabular}{|c|c|c|c|c|}
\hline Hypothesis & Effect & Path coefficient & p-value & Supported? \\
\hline $\mathrm{H} 1: \mathrm{ECHQ}-\mathrm{PCHQ}$ & + & 0.776 & $<0.001^{* * *}$ & YES \\
\hline $\mathrm{H} 2: \mathrm{EPQ}-\mathrm{PPQ}$ & + & 0.751 & $<0.001^{* * *}$ & YES \\
\hline $\mathrm{H} 3: \mathrm{PPQ}-\mathrm{PV}$ & + & 0.138 & $<0.001^{* * *}$ & YES \\
\hline $\mathrm{H} 4: \mathrm{PCHQ} — \mathrm{PV}$ & + & 0.823 & $<0.001^{* * *}$ & YES \\
\hline $\mathrm{H} 5 \mathrm{PCHQ} \longrightarrow(\mathrm{PV}-\mathrm{SATISFAC})$ & + & 0.109 & $0.007^{* * *}$ & YES \\
\hline $\mathrm{H} 6: \mathrm{PPQ} \longrightarrow(\mathrm{PV}$ —SATISFAC) & + & 0.056 & 0.104 & YES \\
\hline $\mathrm{H} 7:$ PV—SATISFAC & + & 0.648 & $0.000^{* * *}$ & YES \\
\hline H8: SATISFAC—LOYALTY & + & 0.728 & $0.000^{* * *}$ & YES \\
\hline
\end{tabular}

$a=0.001\left(^{* * *}\right), a=0.01(* *), a=0.05(*)$

their visit also recommend and share their cultural and heritage experience with family, friends and co-workers. The public administration aims to preserve culture and heritage and maintain the sustainable value of the cultural heritage sites it manages. For private travel companies that have been trying for years to increase the number of visitors and the number of overnight stays, the loyalty of visiting tourists is the key to achieving their goal, which will also increase employment and the economy at the destination.
The analysis of the loyalty of tourists in the destination is important for obtaining excellence in tourist destinations. In this study, a model of structural equations was generated in which latent modulating variables of the main components that are part of satisfaction were implemented. The loyalty of the visiting tourist especially interested in the heritage and culture of the selected destination is analyzed. The results obtained in the study confirmed the hypotheses proposed in the theoretical 


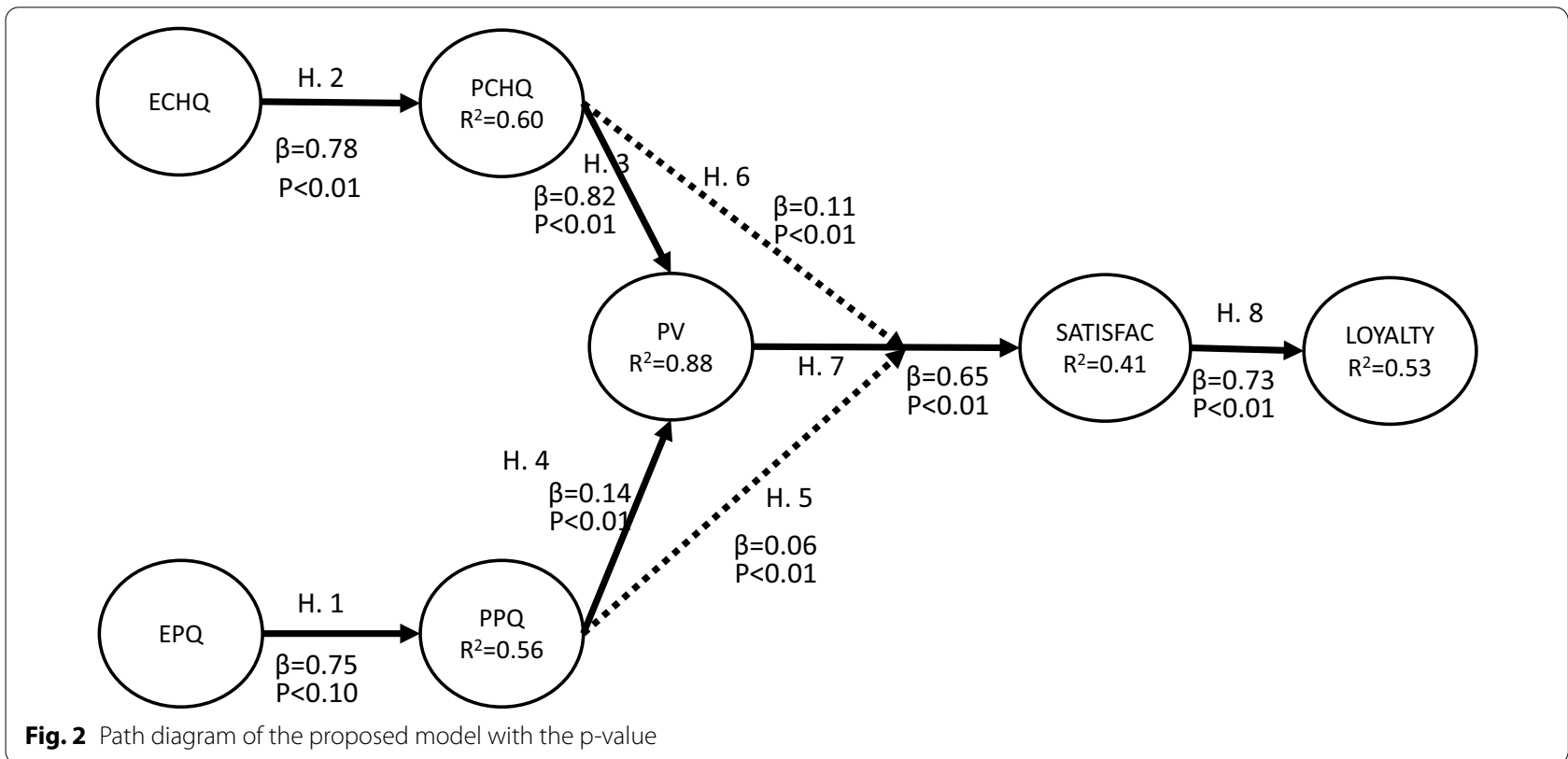

model and can be used to improve the competitiveness of a destination.

The main variables that influenced the choice of the destination city were the cultural and heritage quality that I expected to find when choosing to visit a city declared a World Heritage Site and the recommendation and loyalty of other visitors to the destination [105-107].

At the end of the visit to a world heritage city, the tourist evaluates the gap between the cultural and heritage quality that he expects at the time he prepares the visit, collects information and creates a preconceived idea of the destination and the one he perceives once arrives at the destination, has an experience through the professionals, the accommodations, the monuments and the heritage city as a whole. All this set of sensations and perceptions converge in the satisfaction of the visiting tourist, it gave a feeling of satisfaction that made the visitors recommend it to others as a tourist destination.

Hypothesis 1 The expected cultural quality of the visitor positively and significantly influences the perceived cultural quality. In Fig. 3, the sinusoidal behavior of this variable can be observed, and shows that for very high values of expected cultural quality there is no direct influence on perceived cultural quality. This result coincides with studies by $[69,108]$. Heritage managers must organize cultural activities at and around the heritage site. These activities increase the expected quality and therefore also the perceived quality. Visitors commented that they would like to see theatrical activities together with

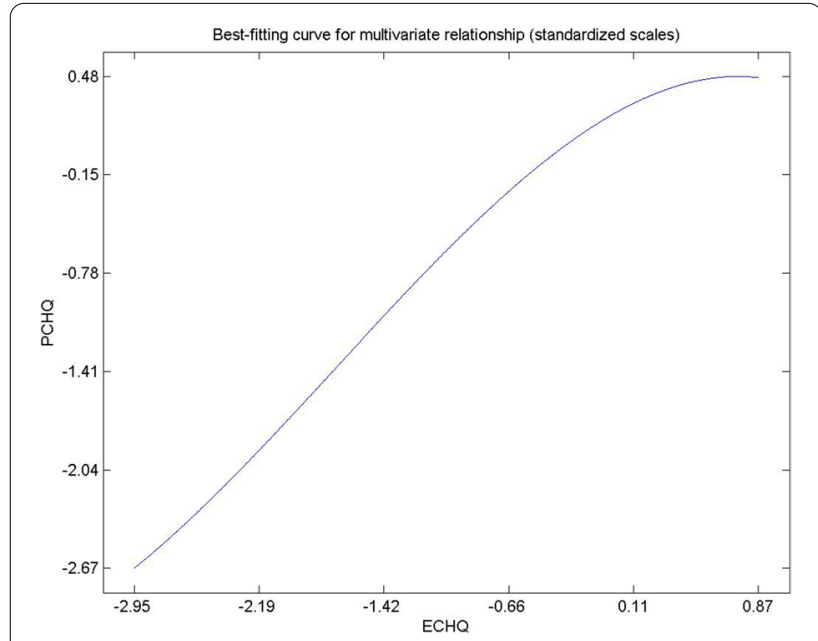

Fig. 3 Hypothesis $1 \mathrm{ECHQ}-\mathrm{PCHQ}$

specialist guides at the destination to increase their satisfaction with the visit.

Hypothesis 2 The expected heritage quality of the visitor positively and significantly influences the perceived heritage quality. In Fig. 4 the sinusoidal behavior means that for very high values of expected heritage quality there is no direct influence on the perceived heritage quality. This confirms studies by $[71,92]$. This result suggests that the digital information available online and the information on display at the destination must be increased. The tourists interviewed in the study claimed 


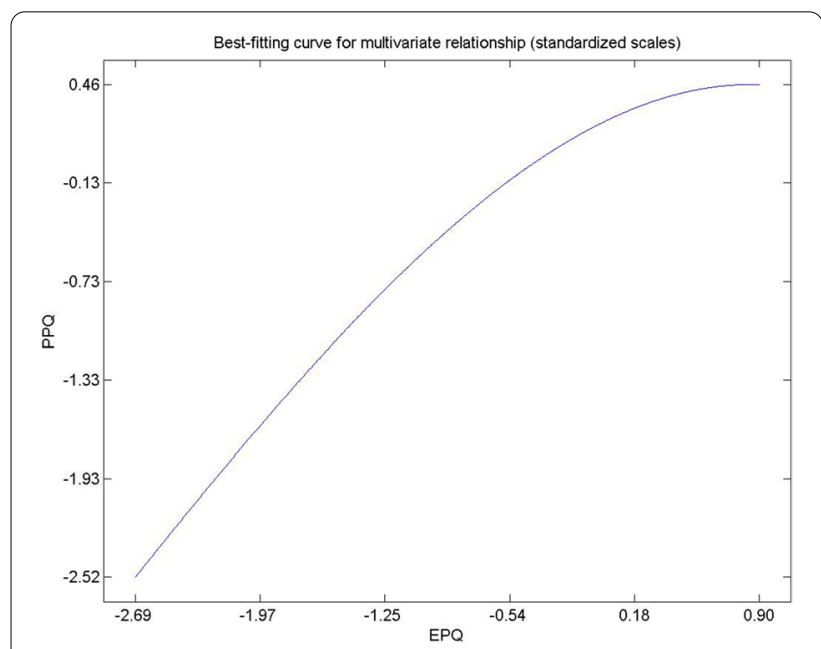

Fig. 4 Hypothesis $2 \mathrm{EPQ}-\mathrm{PPQ}$

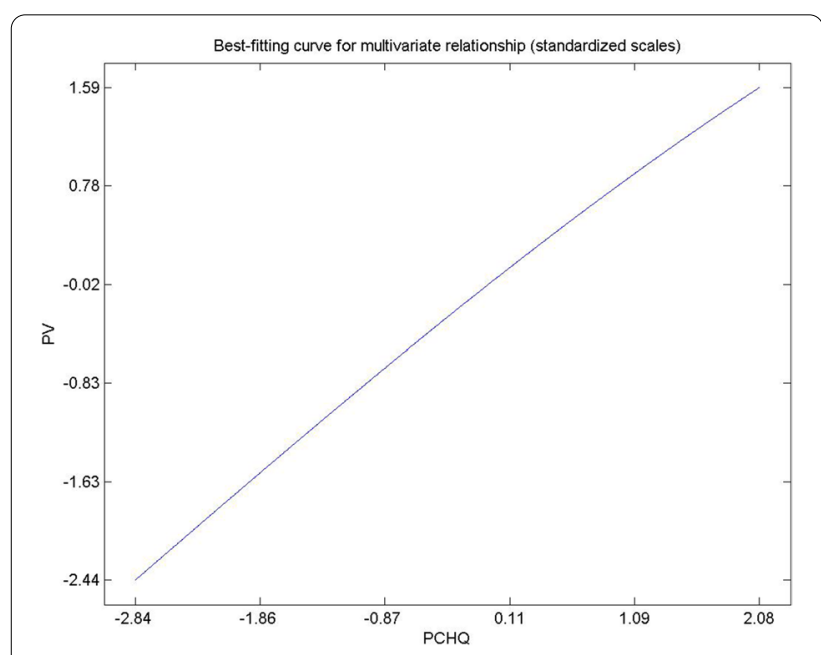

Fig. 6 Hypothesis 4 PCHQ-PV that there were not many references to this heritage site in terms of videos, photography, etc. and therefore they did not have any references for the expected quality of the heritage, which means that the perceived heritage quality was diminished.

Hypothesis 3 The perceived heritage quality of the visitor positively and significantly influences the perceived value of the destination as a whole. Figure 5 shows how the perceived value changes as the perceived heritage quality increases. These results coincide with other studies about heritage [71]. This means that managers of heritage sites should think about improving the maintenance at the site.

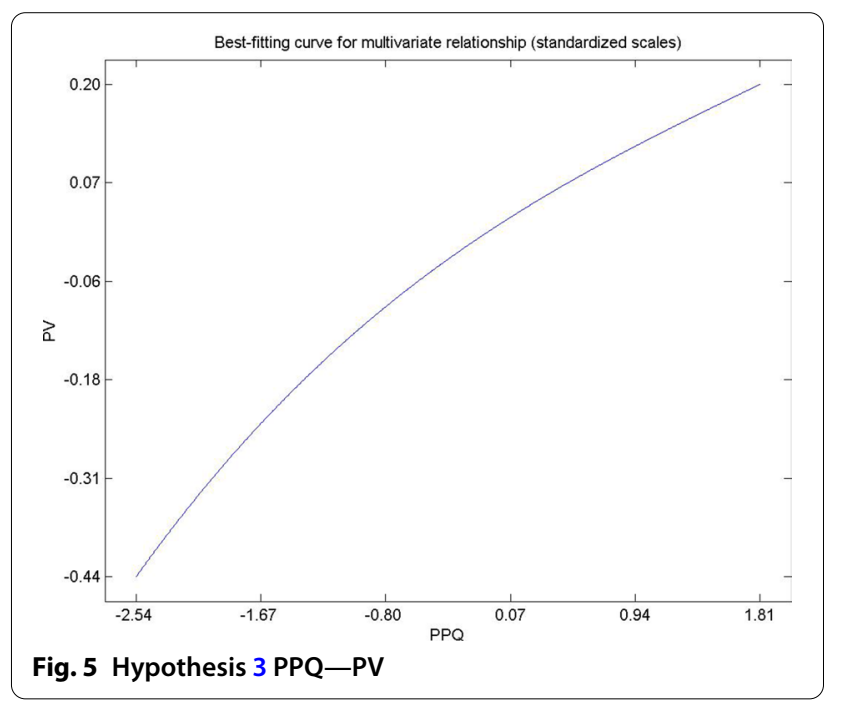

Hypothesis 4 The perceived cultural quality of the visitor positively and significantly influences the perceived value of the destination as a whole. Figure 6 shows the linear influence of perceived cultural quality on the total perceived value. This result coincides with the research of [109]. Heritage managers should be aware of the cultural quality of the heritage. A pile of stones means nothing without the culture that is attached to it. Therefore, heritage managers must make sure that the culture that is associated with a site is explained in the tourists visits.

Hypothesis 5 (Fig. 7a) The perceived cultural quality (PCHQ) of the visitor positively and significantly modulates the relationship between perceived value and satisfaction. Figure $7 \mathrm{~b}$ shows that for a range of low moderating variable values (perceived cultural quality-PCHQ), in the face of unit increases in perceived value (PV), satisfaction (SATISFAC) increases more than proportionately; for a range of perceived cultural quality high values (PCHQ), in the face of unit increases in perceived value $(\mathrm{PV})$ visitor satisfaction increases less than proportionately. Therefore, for both low values and high values of perceived cultural quality (PCHQ) the satisfaction (SATISFAC) of the visiting tourist increases in the face of increases in perceived value (PV). This matches the results found by other authors $[68,73]$. This means that increasing the quality of the heritage helps to increase the overall satisfaction of the tourist with the experience lived.

Hypothesis 6 (Fig. 8a) The perceived heritage quality (PPQ) by the visitor positively and significantly moderates the relationship between perceived value (PV) and satisfaction (SATISFAC). Figure $8 \mathrm{~b}$ shows that in a 

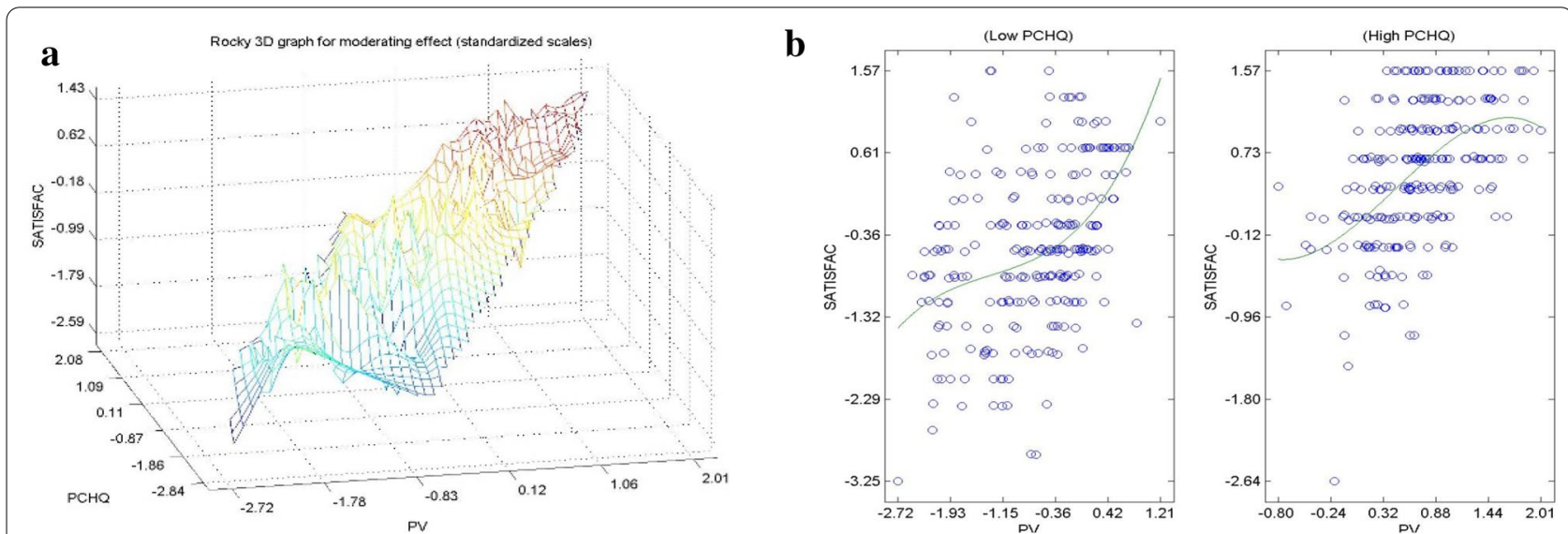

Fig. 7 a. Hypothesis 5 3D. PCHQ $\longrightarrow$ (PV—SATISFAC). b Hypothesis 5 2D. PCHQ $\longrightarrow$ (PV—SATISFAC)
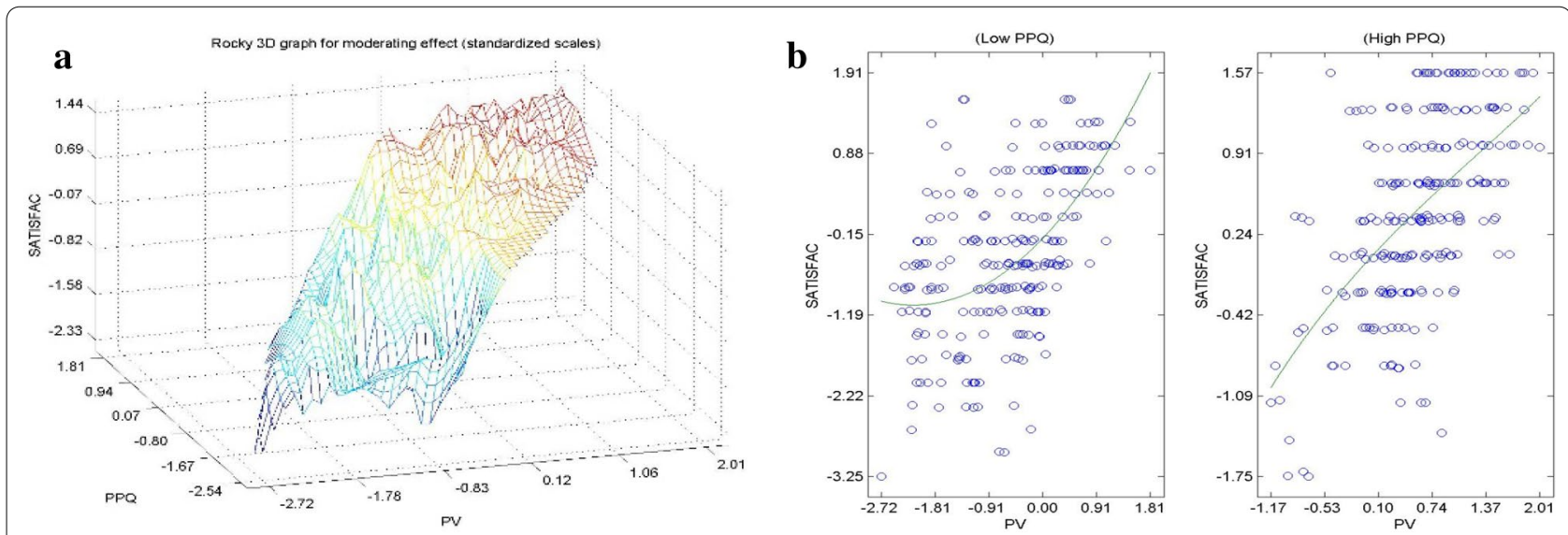

Fig. 8 a. Hypothesis 6 3D. PPQ $\longrightarrow$ (PV—SATISFAC). b Hypothesis 6 2D. PPQ $\longrightarrow$ (PV—SATISFAC)

range of low values of the modulating variable (perceived quality of equity-PPQ), in the face of unit increases in perceived value (PV) satisfaction grows more than proportionally. In a range of high values of the moderating variable, the relationship between perceived value and satisfaction is linear. This coincides with the results of studies by other authors $[110,111]$. That is, for both low values and high values of the modulating variable, satisfaction (SATISFAC) increases as the perceived value (PV) increases. We can say that in view of increases in the quality of the heritage, increasing the perceived value of the site increases the satisfaction of the tourist. Increasing the quality of perceived heritage helps to increase overall satisfaction with the tourist experience.

Hypothesis 7 The perceived value of the visit influences visitor satisfaction with the heritage site. Figure 9 shows that for values of -1.8 and more the expected cultural quality has a linear and direct influence on perceived cultural quality and for very low values this behavior is

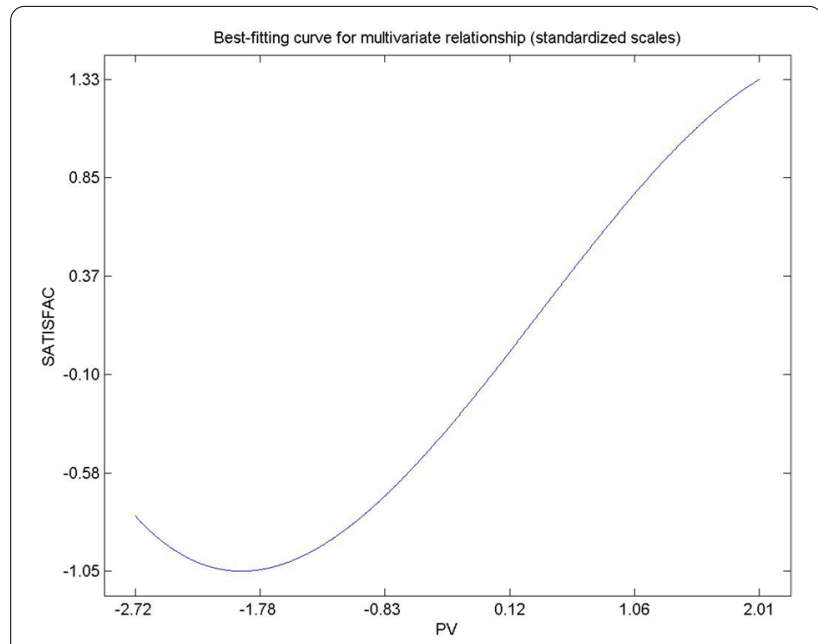

Fig. 9 Hypothesis 7 PV - SATISFAC 
reversed. This result has also been observed by other authors $[105,112,113]$. This result means that for the case being studied, and for cultural heritage in general, the visitor satisfaction can be increased by providing information about the history and the culture of the site. This can be done by having rooms dedicating to the cultures that inhabited the heritage site and explaining the significant milestones that took place there. A high entrance price without offering much cultural and heritage information is counterproductive for the perceived value.

Hypothesis 8 was also confirmed, showing the direct influence that visitor satisfaction in a destination has on tourist loyalty. Figure 10 shows the sine behavior of this relationship. Only in very low extreme values and very high satisfaction, it has no effect on the loyalty of the visiting tourist. For non-extreme values of satisfaction, in the face of increased satisfaction, there are proportional increases in tourist loyalty. The results showed that satisfaction, quality and expectations are positive factors that influence the visitor's decision to return, and recommend a destination. This coincided with the results of other studies $[108,114]$. This study confirmed the relationship between the high satisfaction of the tourist with the heritage of Cordoba and the willingness of tourists to return and recommend the Citadel of the Catholic King. This means that tourists' loyalty from cultural heritage to heritage is high, even though deficiencies that affected heritage expectations were also identified. These deficiencies included the lack of a website dedicated to the site and the lack of advertising. Deficiencies affecting tourist satisfaction were also found. These include the lack of specialized guides, the

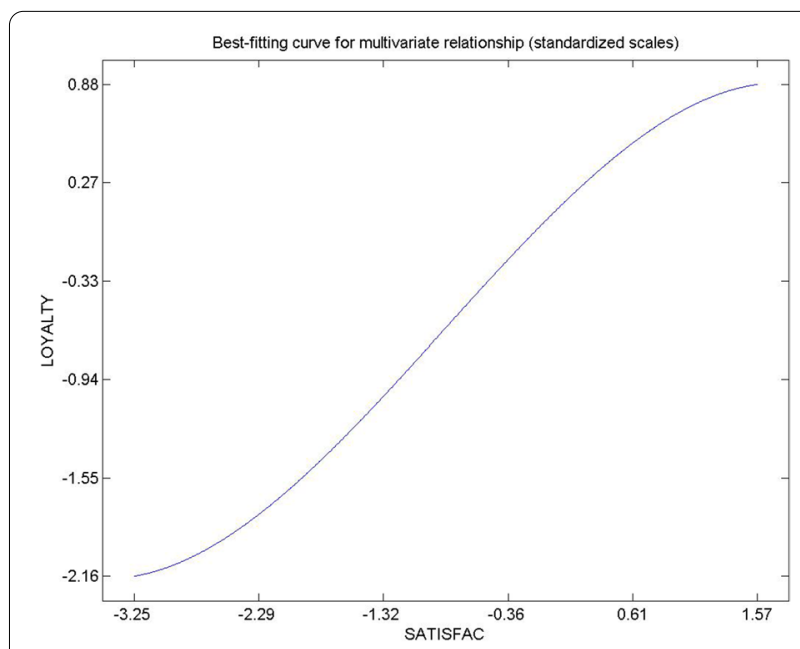

Fig. 10 Hypothesis 8 SATISFAC - LOYALTY lack of theatrical visits, the lack of signs and indications and the lack of information on the culture and history of heritage. The latter affects loyalty. Although tourist satisfaction was generally acceptable, there were too many irregularities to achieve tourist loyalty.

This study outlines a reachable goal for the managers of the heritage in Cordoba so that the experience of visitors to the city can be maximized. This means that having visitors who are satisfied with their visit becomes one of the main reasons to exhibit the heritage. The results of this study agree with those found in previous studies $[59,115]$ which indicate that satisfaction has a positive influence on loyalty to the destination, and encourages the tourist to return to the destination in the future and to recommend it to family and friends. This study states the most important factors to achieve loyalty of heritage tourists in a city which has been home to various cultures, and where there are different heritage sites that show the cultures that have inhabited the city.

This study identifies various factors which visitors to the city consider important when visiting a heritage site. The conservation and cleanliness of the heritage site were valued highly, as was the fact that the heritage sites are inside, or close to, the historical city center. In this way, Cordoba unites and links the tourist to the destination, which positively influences loyalty to the city. The brand created by this set of heritage sites, together with the perceived quality of the visit are factors which can be used to attract tourists who want to experience local culture by visiting these sites [95].

As general conclusions regarding the theoretical implications this research demonstrates, supports and verifies how variables in tourism affect each other. Research, search and study of new relationships and new variables becomes essential. Therefore, we must continue to study the different variables and their relationships in favor of the loyalty of the tourist in the destination. The practical implications for managers of this type of heritage is the importance of focusing on those who visit the heritage: that is, you have to think about all the tourist flows, motivations, moods, but always with the aim of giving a complete tourist experience and the highest quality for those who visit the heritage.

The limitations of this study were due to the sample which was used. The data was obtained from heritage tourists at The Citadel of the Catholic King, which means that the collected data is only valid for one type of tourist at one destination. It would be desirable to study elsewhere where kings stayed overnight and placed their base outside the capital. Another limitation is to perform the study at a time, being convenient to do it temporarily to see the evolution. Similarly, measuring loyalty as the intention of future behavior is a limitation of this study. 
Finally, loyalty does not always mean accurate behavior, the tourist can have amazing behavior [116].

For future lines of research, this study could be carried out in other destinations in Spain such as Madrid or Ibiza which have Alcazares of Catholic kings placed in tourist value, and the results obtained in this work could be compared with those of other destinations. Another possible line of research could be to perform this same study, but aimed at international tourists, in order to examine their motivations and thus establish a segmentation of the touristic offerings of the community according to the type of tourist, national or international.

On the other hand, this study does not deepen and concrete in the tourist experiences around the culture and heritage of a historical heritage asset and how each one affects the value of loyalty and recommendation, therefore, is a future line of research.

\section{Acknowledgements}

Not applicable.

\section{Authors' contributions}

Conceptualization, AV-R and RDH-R; methodology, JAJR and Al-F; software, JAJR and RDH-R; validation JAJR; RDH-R and AV-R; formal analysis, JAJR; RDH-R; Al-F; investigation, AV-R and $\mathrm{RDH}-\mathrm{R}$; resources, AV-R and $\mathrm{RDH}-\mathrm{R}$; data curation, $\mathrm{RH}-\mathrm{R}$ and Al-F; writing - original draft preparation, AV-R; writing - review and editing, AV-R, Al-F; visualization, AV-R; supervision, JAJR; project administration, $\mathrm{N} / \mathrm{A}$; funding acquisition, N/A.

\section{Funding}

This research received no external funding.

\section{Availability of data and materials}

Availability of data and materials in the editorial manager.

\section{Declarations}

\section{Competing interests}

The authors declare that they have no competing interests.

\section{Author details}

${ }^{1}$ Department Agricultural Economics, Sociology, and Policy, Faculty of Economics and Business Sciences, Universidad de Córdoba, Plaza de Puerta Nueva S/N, 14002 Cordoba, Spain. ${ }^{2}$ Management, International Relations, University of Science and Technology, Fujairah, UAE. ${ }^{3}$ Department of Research, Ecotec University, Samborondón-Ecuador and Espiritu Santo University, Samborondón, Ecuador.

Received: 25 February 2021 Accepted: 23 April 2021

Published online: 06 May 2021

\section{References}

1. Kim H, et al. Assessing the economic values of World Heritage Sites and the effects of perceived authenticity on their values. Int J Tour Res. 2018;20(1):126-36.

2. Zhang $\mathrm{H}$, et al. Destination image and tourist loyalty: a meta-analysis. Tour Manage. 2014;40:213-23.

3. Montejo Córdoba AJ. La rauda del Alcázar de Córdoba. 2006.

4. Redondo JFM, et al. Investigaciones arqueológicas en la Muralla de la Huerta del Alcázar (Córdoba). Anejos de anales de arqueología cordobesa. 2009;2:183-230
5. Arjona Fuentes J. Potencialidad De Los Eventos De Religiosidad Popular Como Complemento a La Oferta De Turismo Cultural En La Ciudad De Córdoba (Appeal of Popular Religious Events as a Complement to Cultural Tourist Attractions in the City of Cordova). Available at SSRN 2595585, 2014.

6. Fornell C, et al. The American customer satisfaction index: nature, purpose, and findings. J Mark. 1996;60(4):7-18.

7. Bezerra GC, Gomes CF. Determinants of passenger loyalty in multiairport regions: implications for tourism destination. Tourism Manage Perspect. 2019;31:145-58.

8. Huang S, Weiler B, Assaker G. Effects of interpretive guiding outcomes on tourist satisfaction and behavioral intention. J Travel Res. 2015;54(3):344-58.

9. Jimber del Río JA, et al. Loyalty in heritage tourism: the case of Córdoba and its four world heritage sites. Int J Environ Res Public Health. 2020;17(23):8950

10. Cho M-H. A study of authenticity in traditional Korean folk villages. Int J Hosp Tour Adm. 2012;13(2):145-71.

11. de Sousa EM, et al. Innovation in explaining loyalty: extension of the ACSI model. Rev Admin Em Dialog. 2021;23(1):10-25.

12. Gao B, et al. When online reviews meet ACSI: how ACSI moderates the effects of online reviews on hotel revenue. J Travel Tour Mark. 2020;37:396-408

13. Ali SS, Kaur R. An analysis of satisfaction level of 3PL service users with the help of ACSI. Benchmarking Int J. 2018;25(1):24-46.

14. Kim W-H. The impact of online reviews on customer satisfaction: an application of the American Customer Satisfaction Index (ACSI). Int J Tour Manage Sci. 2017;32(5):65-78.

15. Dani V. Measuring customer satisfaction for F\&B chains in Pune using ACSI model. In: International Conference on Trade, Markets and Sustainability (Ictms-2013), 2014;133:465-472.

16. Sun K-A, Kim D-Y. Does customer satisfaction increase firm performance? An application of American Customer Satisfaction Index (ACSI). Int J Hosp Manage. 2013;35:68-77.

17. Ivanov $\bigvee$, Joseph $K$, Wintoki MB. Disentangling the market value of customer satisfaction: evidence from market reaction to the unanticipated component of ACSI announcements. Int J Res Mark. 2013;30(2):168-78.

18. Park T, Jaegal D. Understanding the satisfaction process of festival visitors through the revised ACSI model: the Andong Mask Dance Festival. J Tour Sci. 2005;28(4):87-105.

19. Ali SS, Kaur R. An analysis of satisfaction level of 3PL service users with the help of ACSI. Benchmarking Int J. 2018;25:24-46.

20. Altunel MC, Erkurt B. Cultural tourism in Istanbul: the mediation effect of tourist experience and satisfaction on the relationship between involvement and recommendation intention. J Destin Mark Manag. 2015;4(4):213-21.

21. Craik J. The culture of tourism. In: Touring cultures. Routledge; 2002. p. 123-46.

22. Poria Y, Butler R, Airey D. Links between tourists, heritage, and reasons for visiting heritage sites. J Travel Res. 2004;43(1):19-28.

23. Ramires A, Brandao F, Sousa AC. Motivation-based cluster analysis of international tourists visiting a World Heritage City: the case of Porto, Portugal. J Destin Mark Manag. 2018;8:49-60.

24. Burns L, Eaddy M, Moore C, Speno L, McRae H. Heritage tourism handbook: a how-to guide for Georgia. Atlanta, GA, USA: Georgia Department of Natural Resources; 2010.

25. Crespi-Vallbona M. Satisfying experiences: guided tours at cultural heritage sites. J Herit Tour. 2021;16(2):201-17.

26. Jensen O, Li Y, Uysal M. Visitors' satisfaction at managed tourist attractions in Northern Norway: do on-site factors matter? Tour Manage. 2017:63:277-86.

27. Dolnicar S, Yanamandram V, Cliff K. The contribution of vacations to quality of life. Ann Tour Res. 2012;39(1):59-83.

28. Su MM, Wall G, Xu K. Heritage tourism and livelihood sustainability of a resettled rural community: mount Sanqingshan World Heritage Site, China. J Sustain Tour. 2016;24(5):735-57.

29. McCabe S, Johnson S. The happiness factor in tourism: subjective well-being and social tourism. Ann Tour Res. 2013;41:42-65.

30. Gilbert D, Abdullah J. Holidaytaking and the sense of well-being. Ann Tour Res. 2004;31(1):103-21. 
31. Paul J, Modi A, Patel J. Predicting green product consumption using theory of planned behavior and reasoned action. J Retail Consum Serv. 2016;29:123-34

32. Buhalis D, López EP, Martinez-Gonzalez JA. Influence of young consumers' external and internal variables on their e-loyalty to tourism sites. J Destin Mark Manag. 2020;15:100409.

33. Castro CB, Armario EM, Ruiz DM. The influence of market heterogeneity on the relationship between a destination's image and tourists' future behaviour. Tour Manage. 2007;28(1):175-87.

34. Chen C-F, Tsai D. How destination image and evaluative factors affect behavioral intentions? Tour Manage. 2007;28:1115-22.

35. Sato $S$, et al. Adventure tourism motivation and destination loyalty: a comparison of decision and non-decision makers. J Destin Mark Manag. 2018;8:74-81.

36. Kozak M. Repeaters' behavior at two distinct destinations. Ann Tour Res. 2001;28(3):784-807.

37. Kozak M, Rimmington M. Tourist satisfaction with Mallorca, Spain, as an off-season holiday destination. J Travel Res. 2000;38:260-9.

38. Yoon Y, Uysal M. An examination of the effects of motivation and satisfaction on destination loyalty: a structural model. Tour Manage. 2005;26:45-56.

39. Chi CG-Q, Qu H. Examining the structural relationships of destination image, tourist satisfaction and destination loyalty: an integrated approach. Tour Manage. 2008;29:624-36.

40. Hallak R, Assaker G, El-Haddad R. Re-examining the relationships among perceived quality, value, satisfaction, and destination loyalty: a higher-order structural model. J Vacat Mark. 2018:24:118-35.

41. Kang J-W, Lee H, Namkung Y. The impact of restaurant patrons' flow experience on SNS satisfaction and offline purchase intentions. Int $J$ Contemp Hosp Manag. 2018;30:797-816.

42. Yu T-W, Chen T-J. Online travel insurance purchase intention: a transaction cost perspective. J Travel Tour Mark. 2018;35:1175-86.

43. Yuksel A, Yuksel F, Bilim Y. Destination attachment: effects on customer satisfaction and cognitive, affective and conative loyalty. Tour Manage. 2010;31:274-84

44. Wu H-C, Li T. A study of experiential quality, perceived value, heritage image, experiential satisfaction, and behavioral intentions for heritage tourists. J Hospital Tour Res. 2017;41(8):904-44.

45. Jin $\mathrm{N}$, Lee $\mathrm{S}$, Lee $H$. The effect of experience quality on perceived value, satisfaction, image and behavioral intention of water park patrons: new versus repeat visitors. Int J Tour Res. 2015;17:82-95.

46. Loureiro SMC, González FJM. The importance of quality, satisfaction, trust, and image in relation to rural tourist loyalty. J Travel Tour Mark. 2008;25:117-36.

47. Lichtenstein DR, Netemeyer RG, Burton S. Distinguishing coupon proneness from value consciousness: an acquisition-transaction utility theory perspective. J Mark. 1990;54:54-67.

48. Chang L-L, Backman KF, Huang YC. Creative tourism: a preliminary examination of creative tourists' motivation, experience, perceived value and revisit intention. Int J Cult Tour Hospital Res. 2014;8:401-19.

49. Anderson EW, Sullivan MW. The antecedents and consequences of customer satisfaction for firms. Mark Sci. 1993;12:125-43.

50. Cossío-Silva F-J, Revilla-Camacho M-Á, Vega-Vázquez M. The tourist loyalty index: a new indicator for measuring tourist destination loyalty? J Innov Knowl. 2019:4:71-7.

51. Bao YQ. Discerning store brand users from value consciousness consumers: the role of prestige. Adv Consum Res Vol Xxxi. 2004;31:707-12.

52. Chen C-F, Chou S-H. Antecedents and consequences of perceived coolness for Generation $Y$ in the context of creative tourism-a case study of the Pier 2 Art Center in Taiwan. Tour Manage. 2019;72:121-9.

53. Pillai KG, Kumar V. Differential effects of value consciousness and coupon proneness on consumers' persuasion knowledge of pricing tactics. J Retail. 2012;88(1):20-33.

54. Delgado-Ballester E, Hernandez-Espallardo M, Rodriguez-Orejuela A. Store image influences in consumers' perceptions of store brands: the moderating role of value consciousness. Eur J Mark. 2014;48(9-10):1850-69.

55. Parasuraman A, ZeithamI VA, Berry LL. A conceptual model of service quality and its implications for future research. J Mark. 1985;49(4):41-50.

56. Chang S. Experience economy in hospitality and tourism: gain and loss values for service and experience. Tour Manage. 2018;64:55-63.
57. Wong IA, Ji M, Liu MT. The effect of event supportive service environment and authenticity in the quality-value-satisfaction framework. J Hospital Tour Res. 2018;42(4):563-86.

58. Kuo N-T, et al. The asymmetric effect of tour guide service quality on tourist satisfaction. J Qual Assur Hosp Tour. 2018;19(4):521-42.

59. Alrawadieh Z, Alrawadieh Z, Kozak M. Exploring the impact of tourist harassment on destination image, tourist expenditure, and destination loyalty. Tour Manage. 2019;73:13-20.

60. Azhar ME, Prayogi MA, Sari M. The role of marketing mix and service quality on tourist satisfaction and loyalty at samosir. Rev Hospital. 2018;15:124-37.

61. Cronin Jr JJ, Brady MK, Hult GTM. Assessing the effects of quality, value, and customer satisfaction on consumer behavioral intentions in service environments. J Retail. 2000;76(2):193-218.

62. Cabeza Méndez JM. El Real Alcázar de Sevilla. Zabaglia. 2011;8:10-3.

63. Jiménez Castillo P, Navarro Palazón J, Alcázares. alcazabas y almunias durante el periodo taifa (siglo XI): Ios espacios palatinos al servicio de unos poderes en formación. 2016.

64. Csapo J. The role and importance of cultural tourism in modern tourism industry. In: Strategies for tourism industry-micro and macro perspectives. 2012;201-232.

65. Farooq MS, et al. Impact of service quality on customer satisfaction in Malaysia airlines: a PLS-SEM approach. J Air Transp Manag. 2018;67:169-80.

66. Ozdemir B, Çizel B, Bato CR. Satisfaction with all-inclusive tourism resorts: the effects of satisfaction with destination and destination loyalty. Int J Hospital Tour Admin. 2012;13(2):109-30.

67. Nguyen $\mathrm{THH}$, Cheung C. Chinese heritage tourists to heritage sites: what are the effects of heritage motivation and perceived authenticity on satisfaction? Asia Pacific J Tour Res. 2016;21(11):1155-68.

68. Kempiak J, et al. The heritage tourist: an understanding of the visitor experience at heritage attractions. Int J Herit Stud. 2017;23(4):375-92.

69. Ganzaroli A, De Noni I, van Baalen P. Vicious advice: analyzing the impact of TripAdvisor on the quality of restaurants as part of the cultural heritage of Venice. Tour Manage. 2017;61:501-10.

70. Alazaizeh MM, et al. Giving voice to heritage tourists: indicators of quality for a sustainable heritage experience at Petra, Jordan. J Tour Cult Chang. 2019;17(3):269-84.

71. Thanou A, Tsiropoulou EE, Papavassiliou S. Quality of experience under a prospect theoretic perspective: a cultural heritage space use case. IEEE Trans Comput Soc Syst. 2019;6(1):135-48.

72. Mansor N, et al. Mosque tourism certification in Wagf management: a model by Ukhwah Samara. Soc Sci Human. 2015;23:291-304.

73. Donthu N, Yoo B. Cultural influences on service quality expectations. J Serv Res. 1998;1(2):178-86.

74. Tata J, Prasad S. Cultural and structural constraints on total quality management implementation. Total Qual Manag. 1998;9(8):703-10.

75. Gurung A, Prater E. A research framework for the impact of cultural differences on IT outsourcing. In: Global sourcing of services: strategies, issues and challenges. World Scientific; 2017. p. 49-82.

76. Chen C-F, Chen F-S. Experience quality, perceived value, satisfaction and behavioral intentions for heritage tourists. Tour Manage. 2010:31(1):29-35.

77. Jeon MM, Kang MM, Desmarais E. Residents' perceived quality of life in a cultural-heritage tourism destination. Appl Res Qual Life. 2016;11(1):105-23.

78. Lee $\mathrm{S}$, et al. Heritage tourism in Singapore Chinatown: a perceived value approach to authenticity and satisfaction. J Travel Tour Mark. 2016;33(7):981-98.

79. Agyeiwaah $\mathrm{E}$, et al. Understanding culinary tourist motivation, experience, satisfaction, and loyalty using a structural approach. J Travel Tour Mark. 2019:36(3):295-313.

80. Thi K, et al. The effects of service quality on international tourist satisfaction and loyalty: insight from Vietnam. Int J Data Netw Sci. 2020;4(2):179-86

81. Marshall PA. Cultural influences on perceived quality of life. In: Seminars in oncology nursing. Elsevier; 1990.

82. Pouso S, Uyarra MC, Borja Á. The recovery of estuarine quality and the perceived increase of cultural ecosystem services by beach users: a case study from northern Spain. J Environ Manage. 2018;212:450-61. 
83. Mohseni $\mathrm{S}$, et al. Attracting tourists to travel companies' websites: the structural relationship between website brand, personal value, shopping experience, perceived risk and purchase intention. Curr Issue Tour. 2018;21(6):616-45.

84. Nilson TH. Value-added marketing: marketing management for superior results. McGraw-Hill Book Company; 1992.

85. Pandža Bajs I. Tourist perceived value, relationship to satisfaction, and behavioral intentions: the example of the Croatian tourist destination Dubrovnik. J Travel Res. 2015;54(1):122-34.

86. Tom Dieck MC, Jung TH. Value of augmented reality at cultural heritage sites: a stakeholder approach. J Destinat Market Manag. 2017;6(2):110-7.

87. Gallarza MG, Maubisson L, Rivière A. Replicating consumer value scales: a comparative study of EVS and PERVAL at a cultural heritage site. J Bus Res. 2020;126:614-23.

88. Qi L, et al. Time-aware distributed service recommendation with privacy-preservation. Inf Sci. 2019;480:354-64.

89. Hallak R, Assaker G, El-Haddad R. Re-examining the relationships among perceived quality, value, satisfaction, and destination loyalty: a higher-order structural model. JVacat Mark. 2018;24(2):118-35.

90. Cheng BL, et al. Service recovery, customer satisfaction and customer loyalty: evidence from Malaysia's hotel industry. Int J Qual Serv Sci. 2019;11:187-203.

91. Hosany S, Prayag G. Patterns of tourists' emotional responses, satisfaction, and intention to recommend. J Bus Res. 2013;66(6):730-7.

92. Domínguez-Quintero AM, González-Rodríguez MR, Paddison B. The mediating role of experience quality on authenticity and satisfaction in the context of cultural-heritage tourism. Curr Issue Tour. 2020;23(2):248-60.

93. Veasna S, Wu W-Y, Huang C-H. The impact of destination source credibility on destination satisfaction: the mediating effects of destination attachment and destination image. Tour Manage. 2013;36:511-26.

94. Assaker G, Vinzi VE, O'Connor P. Examining the effect of novelty seeking, satisfaction, and destination image on tourists' return pattern: a two factor, non-linear latent growth model. Tour Manage. 2011;32(4):890-901.

95. San Martín H, Herrero A, García de los Salmones MdM. An integrative model of destination brand equity and tourist satisfaction. Curr Issues Tour. 2019;22(16):1992-2013.

96. Gómez-Zapata JD, Espinal-Monsalve NE, Herrero-Prieto LC. Economic valuation of museums as public club goods: why build loyalty in cultural heritage consumption? J Cult Herit. 2018;30:190-8.

97. Verma A, Rajendran G. The effect of historical nostalgia on tourists' destination loyalty intention: an empirical study of the world cultural heritage site-Mahabalipuram, India. Asia Pacific J Tour Res. 2017;22(9):977-90.

98. Fu X. Existential authenticity and destination loyalty: evidence from heritage tourists. J Destin Mark Manag. 2019;12:84-94.

99. Henseler J, Chin WW. A comparison of approaches for the analysis of interaction effects between latent variables using partial least squares path modeling. Struct Equ Model. 2010;17(1):82-109.

100. Carmines EG, Zeller RA. Reliability and validity assessment, vol. 17. USA: Sage publications; 1979.
101. Barclay D, Higgins C, Thompson R. The partial least squares (PLS) approach to casual modeling: personal computer adoption ans use as an Illustration. 1995.

102. Hair JF, Ringle CM, Sarstedt M. Partial least squares: the better approach to structural equation modeling? Long Range Plan. 2012;45(5-6):312-9.

103. Fornell C, Larcker DF. Structural equation models with unobservable variables and measurement error: algebra and statistics. USA: SAGE Publications; 1981.

104. Nunnally JC, Bernstein IH. Psychometric theory. New York: McGraw-Hill; 1978.

105. Su L, Hsu MK, Swanson S. The effect of tourist relationship perception on destination loyalty at a world heritage site in China: the mediating role of overall destination satisfaction and trust. J Hospital Tour Res. 2017;41(2):180-210.

106. Santa-Cruz FG, López-Guzmán T. Culture, tourism and world heritage sites. Tour Manag Perspect. 2017;24:111-6.

107. Cossío-Silva F-J, Revilla-Camacho M-Á, Vega-Vázquez M. The tourist loyalty index: a new indicator for measuring tourist destination loyalty? J Innov Knowl. 2019;4(2):71-7.

108. Chen H, Rahman I. Cultural tourism: an analysis of engagement, cultural contact, memorable tourism experience and destination loyalty. Tour Manag Perspect. 2018;26:153-63.

109. Oriade A, Schofield P. An examination of the role of service quality and perceived value in visitor attraction experience. J Destin Mark Manag. 2019:11:1-9.

110. Sánchez-Sánchez MD, De-Pablos-Heredero C, Montes-Botella JL. A behaviour model for cultural tourism: loyalty to destination. Econ Res Ekonomska Istraživanja, 2020;1-18.

111. Elmoussaoui M. The phenomenological significance of dwelling in architecture. The case of Eastern Beka'a Valley-Lebanon. 2020.

112. Liu Y, et al. Understanding the relationship between food experiential quality and customer dining satisfaction: a perspective on negative bias. Int J Hosp Manag. 2020;87:102381.

113. Alnawas I, Hemsley-Brown J. Examining the key dimensions of customer experience quality in the hotel industry. J Hosp Market Manag. 2019;28(7):833-61.

114. Prayag G, et al. Understanding the relationships between tourists' emotional experiences, perceived overall image, satisfaction, and intention to recommend. J Travel Res. 2017;56:41-54.

115. Su Y, Teng W. Contemplating museums' service failure: extracting the service quality dimensions of museums from negative on-line reviews. Tour Manage. 2018;69:214-22

116. Bodet G. Loyalty in sport participation services: an examination of the mediating role of psychological commitment. J Sport Manag. 2012;26(1):30-42.

\section{Publisher's Note}

Springer Nature remains neutral with regard to jurisdictional claims in published maps and institutional affiliations.

\section{Submit your manuscript to a SpringerOpen ${ }^{\odot}$ journal and benefit from:}

- Convenient online submission

- Rigorous peer review

- Open access: articles freely available online

- High visibility within the field

- Retaining the copyright to your article

Submit your next manuscript at $\boldsymbol{\nabla}$ springeropen.com 